\title{
A BALKÁNI GERLE (Streptopelia decaocto) KEZELÉSI TERVE MAGYARORSZÁGON
}

\author{
Faragó Sándor ${ }^{1} \&$ Juhász Lajos ${ }^{2}$ \\ 1: Soproni Egyetem, Vadgazdálkodási és Gerinces Állattani Intézet \\ University of Sopron, Institute of Wildlife Management and Vertebrate Zoology \\ H-9400 Sopron, Bajcsy-Zs u. 4., Hungary \\ E-mail: farago.sandor@uni-sopron.hu \\ 2: Debreceni Egyetem, Természetvédelmi Állattani és Vadgazdálkodási Tanszék \\ University of Debrecen, Department of Nature Conservation, Zoology and Game Management \\ H-4032 Debrecen, Böszörményi út 138., Hungary \\ E-mail: juhaszl@agr.unideb.hu
}

FARAGÓ S. \& JUHÁSZ L. (2019): MANAGEMENT PLAN FOR EURASIAN COLLARED DOVE (Streptopelia decaocto) IN HUNGARY. Hungarian Small Game Bulletin 14: 69-92. http://dx.doi.org/10.17243/mavk.2019.069

\section{A BALKÁNI GERLE (Streptopelia decaocto) BIOLÓGIÁJA ÉS ÖKOLÓGIÁJA, A VÉDELMI GYAKORLAT ÉRTÉKELÉSE}

\subsection{BEVEZETÉS}

A balkáni gerle Európában biztos állományú (S) faj (TuCKER \& HEATH, 1994). A Berni Egyezmény III. Mellékletében és az EU Madárvédelmi Irányelvek II/2. Mellékletében szerepel. Dinamikájára a vadászati hasznosítás van/lehet - közvetlen és közvetett módon negatív hatással. Állománynagyságát befolyásolja az élőhelyek átalakulása, a fontosabb tápláléknövények (napraforgó) vetésterületének, táblanagyságának csökkenése, a ragadozók zsákmányolása (természetes ellenségei falvakban a macskák, a parkokban, arborétumokban a szajkó, a csóka és a mókus és a héja), a magas állománysürüség mellett fellépô betegségek és a kemény telek. Magyarországon vadászható madárfaj, 1993-ig egész évben vadászható volt, jelenleg vadászidénye augusztus 1 . - január 31. között van. Különösebb védelmi intézkedésre nem szorul.

\section{2. ÖKOLÓGIA}

\subsection{1.Élőhelyi feltételek}

A balkáni gerle terjeszkedését elösegítette, a kultúrterületek viszonylagos madár-üressége, azaz az itt őshonos fajokhoz képest e területeket jól be tudta lakni, az számára (növényevő fajként) alkalmasnak bizonyult (RÉKÁsı 1980). Fenti jelenség is igazolja, hogy a balkáni gerle kultúrakövető faj. Egyes populációi kimondottan emberi településekre, illetve azok köré települtek, de mezőgazdasági területeken is előfordul, mint fészkelő. Olykor erdőszélek, galéria erdők is otthont adnak neki, bár az utóbbi időben ezekről a területekről is eltünik és a települések köré koncentrálódik. Szívesen telepszik meg parkokban, ahol korábban óriási csapatokba verődve éjszakázott, s kijár a mezőgazdasági területekre táplálkozni. Ugyanilyen okból csoportosul télen az állattartó telepek, magtárak köré (FARAGÓ 2015). 


\subsubsection{Szaporodás}

Ivarérettség: Elsőéves korban ivarérett, olykor azonban a születési évében, 2,5-4 hónappal a kelés után, már költhet.

Ivari kapcsolata: A balkáni gerle monogám, rendszerint egy költési időszakra vonatkozik a párkapcsolat. A pároknak a következő szaporodási idényben való összetartása viszonylag gyakori, ami a másik egyed felismerésén, illetőleg a territórium hüségen alapszik. A nagyobb populációkban a párok a szaporodási ciklusok között is összetartanak, talán élethossziglan is. A párban álló hím olykor idegen tojót is körül udvarolhat, ilyenkor párzás és partnerváltás is bekövetkezhet. Valószínüsítik többnejüségét (poligynia) is. Közép-Európában a párzási időszak február-augusztus között jellemző, de előfordul, hogy más hónapokban is hallatszik hívó hangja egy-egy hímnek, különösen enyhe időjárás esetén. A territóriumot vagy csak a hím, vagy már a pár együtt foglalja el a tél végén, amikor a téli balkáni gerle csapatok felbomlanak. Idősebb madaraknál ez február/márciusban, a fiatal madaraknál a születésük évében is bekövetkezhet. Kedvező időjárási, táplálkozási vagy alvóhelyi viszonyok mellett a hím, vagy a pár gyakran a költési időszakon kívül is a territóriumban tartózkodik. A hímek jelzőrepülése és jellegzetes hívó hangja egyszerre szolgálja a territórium megjelölését és a figyelemfelkeltést. A tojók ritkán mutatkoznak, szemmel láthatóan csak a partnernek mutatják magukat. A hím egy magaslatról, sokszor hangos szárnycsapkodás mellett felemelkedik (maximum $30 \mathrm{~m}$ ), azután egy ívben vagy csigavonalban a kiindulási pontra, esetleg attól távolabb ereszkedik vissza. Közben a szárnyát vízszintesen tartja, farkát terpeszti, hogy a farok fekete-fehér kontrasztos mintázata jól látható legyen. Ha egy tojó közeledik a párzásra kész hím felé, akkor az egy hívóhanggal, kérkedve fogadja. A kérkedő hívás első strófája közben a hím meghajol a tojó előtt. Az első strófát még további kettő követi. Ha a tojó elfogadja a hím udvarlását, akkor csőrét nyújtja a hímnek, ami a párzás bevezetése. Eközben a tojó leszorítja a fejét, megemeli és ellazítja szárnyait, miközben a hím ráugrik, vagy ráröppen a hátára. A kopuláció után turbékoló hangot adnak (GLUTZ \& BAUER 1980).

Költési idő: A balkáni gerle gyakorlatilag egész évben költhet, bár a kemény telek miatt a februártól novemberig terjedő időszakban aktívak igazán (GLUTZ \& BAUER, 1980). KEVE (1960) többször megfigyelt téli költését közölte. BOZSKO (1976b) novemberi sikeres és decemberi-januári sikertelen költéséről tudósított Debrecenből.

A fészek helye: A fészek helyét a tojó választja ki a hím által kínált fészkelő helyek közül. Fészkét föként fákra és bokrokra építi. Az urbanizálódott madarak a legkülönfélébb módját választják a fészkelésnek. A hagyományos fészkelőhelyek mellett nem ritka, hogy nagyvárosi házak erkélyein virágládában, épület beszögellésekbe, vasúti várócsarnokok, gyárépületek belsejébe, lámpaoszlopokra és lámpatestekre építi fészkét. Nem ritka, hogy más madárfajok (örvösgalamb, vadgerle, feketerigó) elhagyott fészkére épít rá (TOMASZ 1955, STOLLMANN 1957, HADARICS 1992, HARASZTHY 2019)

A fészek laza szerkezetü, amit a tojó rak meg azokból az anyagokból, amiket a hím főként a talajról gyüjtöget. A fészekrakás általában 3-4 napot vesz igénybe. Amilyen különleges tud lenni a fészek helyének kiválasztásában, ugyanilyen különleges a fészek anyagában is. Különösen a városiasodott balkáni gerlék használnak sok hulladékot (drót, fólia, zsineg, stb.) alternatív fészekanyagként. HARASZTHY (2019) említést tesz fekete fenyőn (Pinus nigra), kizárólag fenyőtűből készített fészekről is.

Tojásrakás, költésszám: A szaporodási időszak 10 hónapja alatt 4-5 fészekaljat is felnevelhet. A tojásokat 1-2 naponta (36-48 óra) helyezi a fészekbe a tojó.

A fészekalj nagysága: (1-)2(-3), de csaknem kizárólag 2-es fészekalja van. Magyarországi fészekaljak (n=92) 98\%-a 2-es, 1-1\%-a egyes és hármas volt (FARAGÓ, 2001a), míg HARASZTHY (2019) a magyar tojásgyüjteményekben található fészekaljak $(n=165)$ alapján 162-ben talált 2 tojást, s csak 3 esetben 3-at. 
A tojások alakja ovális, néha rövid ovális vagy ellipszis alakúak lehetnek, színük fehér, felszínük finoman szemcsézett, enyhén fényes. Közép- és délkelet-európai balkáni gerle tojások átlagos mérete $\mathrm{D}_{22}: 31,65 \times 24,19 \mathrm{~mm}$, tömege 9,6 g (MAKATSCH 1976), a cseheké $\mathrm{D}_{698}$ : 30,6 $\times 23,6 \mathrm{~mm}$, az 1. tojások tömege 9,3 a 2. tojásoké 9,9 g (PIKULA \& KUBIK, 1978) volt. Magyarországon mért tojások $(n=184)$ jellemző értékei az alábbiak (FARAGÓ 2001a).

$\begin{array}{ll}\mathrm{D}_{184}: & 30,59 \times 23,50 \mathrm{~mm} \\ \mathrm{H}_{\min } . & 23,71 \times 20,42 \mathrm{~mm} \\ \mathrm{Sz}_{\min } . & 27,63 \times 20,32 \mathrm{~mm} \\ \mathrm{I} & 1,303 \\ \mathrm{I}_{\min } & 1,16\end{array}$

$$
\begin{array}{ll}
\mathrm{H}_{\max } . & 37,85 \times 22,60 \mathrm{~mm} \\
\mathrm{Sz}_{\max } & 32,51 \times 25,75 \mathrm{~mm} \\
\mathrm{I}_{\max } & 1,67
\end{array}
$$

Ez az adatsor tartalmazza a NÉMETH MÁRTON-féle tojásgyüjtemény (SOLTI 2010) adatait is, amelyeket HARASZTHY (2019) az alábbiakban adott meg:

$$
\begin{array}{llll}
\mathrm{D}_{119}: & 30,76 \times 23,50 \mathrm{~mm} & & \\
\mathrm{H}_{\text {min. }} . & 32,0 \times 25,0 \mathrm{~mm} & \mathrm{H}_{\max } . & 37,9 \times 22,6 \mathrm{~mm} \\
\mathrm{Sz}_{\text {min. }} . & 26,7 \times 22,0 \mathrm{~mm} & \mathrm{Sz}_{\max } & 29,2 \times 25,0 \mathrm{~mm}
\end{array}
$$

Kotlás: A kotlás az első tojás lerakása után kezdődik (TOMASZ 1955), de annak intenzitása csak a második tojás lerakása után válik teljessé. Mindkét szülő kotlik, hossza 14-16(-18) nap. A tojó üli a tojásokat egész éjjel, a hím a reggeli órákban váltja fel (MAKATSCH, 1976; CRAMP 1985).

Fiókanevelés: A fiókákat az első napokban még melengetik, s közben mindkét szülő eteti, azok gyorsan fejlődnek, s a 3. héten (15-19., átlagosan a 17. napon), zavarás esetén már 13-15 nap után elhagyják a fészket (1. ábra). Az első 5-10 napban a fészek környékén tartózkodnak, de éjszakázni visszatérnek a fészekbe (BOZSKO 1979). Veszély estén a fészekből kiugró fiatalok 14-15 naposan rövid távolságról (legfeljebb $60 \mathrm{~m}$ ) már repülve térnek vissza a fészekbe (GLUTZ \& BAUER 1980; CRAMP, 1985).

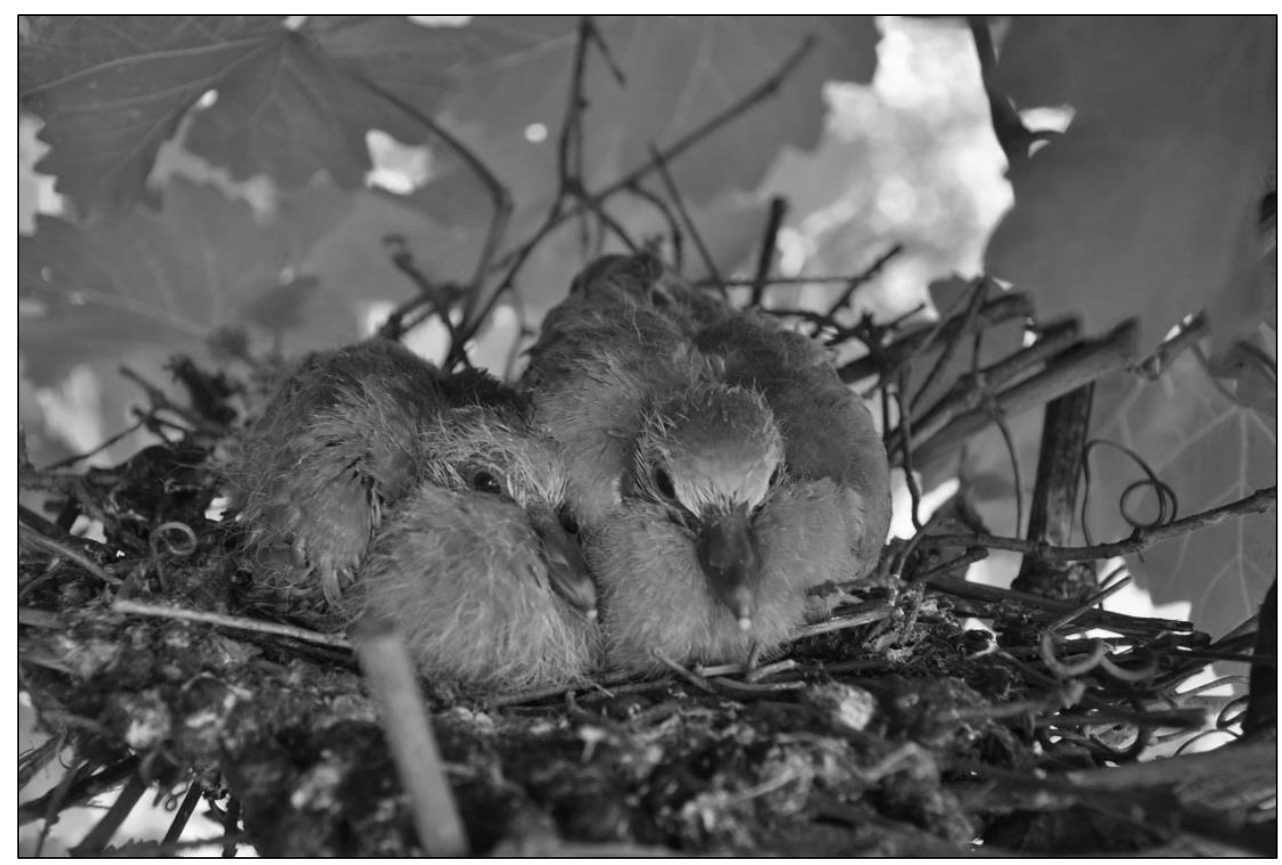

1. ábra: Balkáni gerle fészekalj (Fotó: JUHÁsz L.)

Figure 1: Nestlings of Eurasian Collared Dove (Photo: JUHÁSZ L.) 
Költési eredmény, halandóság: Németországban a fészekaljaknak 65,5\%-a kikelt, a fiókák 48,6\%-a kirepült. A költési eredmény a szezon elején $31,8 \%$ volt, május-júniusban $50 \%$, augusztus-októberben pedig 70\% (CRAMP 1985). A debreceni populációban, májusban 4,2\%, júliusban 27,6\%, októberben 36,0\% és januárban 8,0\% volt a fiatalok aránya (BOZSKO, 1983). BOzSKO (1983) a városi csókák (Corvus monedula), CRAMP (1985) a szarkák (Pica pica), JUHÁsz (2016) a dolmányos varjak (Corvus cornix) fészekrabló hatását emelte ki. Az átlagos halálozási ráta az 1. évben 50-75\%, a későbbiekben 35-55\% (GLUTZ \& BAUER, 1980). Szabadban 9-10 éves, fogságban tartott balkáni gerle esetében 25, illetve 29 éves kort is feljegyeztek (GLUTZ \& BAUER, 1980). Csaknem 100 Nyíregyháza körzetéből származó őszi balkáni gerle teríték anatómiai vizsgálatából kiderült, hogy az ivarmegoszlás a két nem között lényegesen nem különbözik, illetve a fiatal egyedek (immatur, szubadult) aránya is jelentős volt (VARGA \& JUHÁsz 2018). Ez vélhetően az alacsonyabb predátor sürüséggel is magyarázható.

\subsubsection{Táplálkozás}

A táplálkozás napi ciklusának két maximuma van. Napkelte után 1-2 órával lezajló, hosszabb és kevésbé aktív, illetve a napnyugta előtti 1-2 órás dinamikus szakasz (RÉKÁSI 1980). Elsősorban a termesztett növények és gyomnövények magjával táplálkoznak, olykor felszednek csigákat is. A fogyasztott táplálék amiatt, hogy egész évben itt tartózkodik ugyancsak sokféle, ennek dacára a termesztett magok mennyisége abszolút domináns (RÉKÁSI 2000). RÉKÁSI (1975, 1983) napraforgótáblákról begyüjtött balkáni gerlék $(n=234)$ gyomrában, 13 esetben csak gyommagvakat, 104 esetben csak haszonmagvakat, 117 esetben vegyesen gyommagot és haszonmagot talált. Egyféle táplálékot 103, kétféle táplálékot 83, háromféle táplálékot 33, négyféle táplálékot 11 és ötfélét 4 esetben lehetett kimutatni.

A fogyasztott haszonnövények a napraforgó, a búza, a kukorica, a szőlő és a borsó magjai, a leggyakoribb gyommagvak a szulák keserüfü (Bilderdykia convolvulus), a fakó muhar (Setaria lutescens), a madár keserüfü (Polygonum aviculare) voltak. A későbbiekben RÉKÁSI (1980) eltérő állománysürüségü populációk táplálék összetételét vizsgálta. Megállapította, hogy kis és közepes állománysürüségü populációk egyedei többféle táplálékot fogyasztanak, mint a nagyobb állománysürüségü populációkból származó egyedek. Előbbiek háromszor több gyommagot fogyasztottak (38 gyom fajból), mint haszonmagot (13 fajból). Esős időben nagyobb szemü gyom- és haszon magvakat fogyasztottak és csökkent a fajszám is. Nagy balkáni gerle sürüségü helyröl gyüjtött kóborló példányok $(n=234)$ gyomrában, 117 esetben vegyesen volt gyom- és kultúrnövények magja, 104 esetben kizárólag termesztett növény, 13 esetben kizárólag gyomnövény magjait fogyasztották. Az ismétlődő vizsgálatok a balkáni gerle tápláléklistájának alakulásával is igazolták a mezei élőhelyek növényzetének szegényedését. A korábbi 51 féle növény helyett 20 féle növényi termést és magot fogyasztott a balkáni gerle. Ez a flóraszegényedés, illetve a bőséges táplálékkínálat eredményezi a napraforgótáblák felkeresését (1-2. táblázat).

A csigatáplálékkal kapcsolatban végzett vizsgálatok során - mivel nagyobb méretü csigákat nem találtak a mintákban - feltételezték, hogy a magvak felcsipegetése közben, mint magméretü, magnak látszó táplálék került felvételre. Ezt látszik alátámasztani, hogy a jelenlévő nagyobb méretü csigáknak is mindig a kisméretü, fiatal egyedeit szedték fel, tehát méretre és nem táplálékféleségre történt a szelekció (RÉKÁSI \& RICHNOVSZKY 1974).

A költési időszakban végzett vizsgálatok - talán a hosszú költési időszak okán - nem mutatnak lényeges eltérést a teljes vizsgálati évre kimutatott táplálékspektrumhoz képest (3. táblázat). 
1. táblázat: A balkáni gerle táplálékának összetevői kis és közepes állománysürüségü helyeken, Magyarországon (n=149) (RÉKÁSI 1980).

Table 1: Food composition of Eurasian Collared Dove at low and middling population density in Hungary (n=149) (RÉKÁSI 1980).

\begin{tabular}{|c|c|c|c|}
\hline $\begin{array}{l}\text { Táplálék összetevők } \\
\text { Food components }\end{array}$ & $\begin{array}{c}\text { Eset } \\
\text { Presence }\end{array}$ & $\begin{array}{l}\text { Darabszám } \\
\text { Number }\end{array}$ & $\begin{array}{c}\text { Elöfordulási \% } \\
\text { Presence \% }\end{array}$ \\
\hline \multicolumn{4}{|l|}{$\begin{array}{l}\text { Kultúrnövények magvai } \\
\text { Seeds of cultivated plants }\end{array}$} \\
\hline Zea mays mag & 120 & 2012 & 80,5 \\
\hline Vitis vinifera & 49 & 270 & 32,8 \\
\hline Triticum aestivum & 21 & 1360 & 14,0 \\
\hline Helianthus annuus & 18 & 287 & 12,0 \\
\hline Sorghum bicolor & 5 & 570 & 3,3 \\
\hline Hordeum vulgare & 4 & 16 & 2,6 \\
\hline Capsicum annuum & 3 & 19 & 2,0 \\
\hline Malus domestica & 2 & 5 & 1,3 \\
\hline Pisum sativum & 2 & 4 & 1,3 \\
\hline Raphanus sativus & 1 & 198 & 0,6 \\
\hline Cucumis sativus & 1 & 4 & 0,6 \\
\hline Vicia villosa & 1 & 1 & 0,6 \\
\hline Cucurbita maxima & 1 & 1 & 0,6 \\
\hline \multicolumn{4}{|l|}{$\begin{array}{l}\text { Gyommagvak } \\
\text { Seeds of weeds }\end{array}$} \\
\hline Polygonum convolvulus & 49 & 661 & 32,8 \\
\hline Setaria lutescens & 41 & 5219 & 27,5 \\
\hline Convolvulus arvensis & 40 & 290 & 26,8 \\
\hline Amaranthus retroflexus & 36 & 1106 & 24,1 \\
\hline Polygonum aviculare & 27 & 201 & 18,1 \\
\hline Amaranthus blitoides & 22 & 1148 & 14,7 \\
\hline Chenopodium hybridum & 17 & 202 & 11,4 \\
\hline Setaria verticillata & 12 & 44 & 8,1 \\
\hline Setaria viridis & 10 & 386 & 6,7 \\
\hline Convolvulus tricolor & 10 & 164 & 6,7 \\
\hline Amaranthus albus & 10 & 69 & 6,7 \\
\hline Echinochloa crus-gali mag & 8 & 38 & 5,3 \\
\hline Amaranthus deflexus & 7 & 3133 & 4,6 \\
\hline Solanum nigrum & 6 & 132 & 4,0 \\
\hline Chenopodium urbicum & 5 & 19 & 3,3 \\
\hline Reseda lutea & 4 & 4 & 2,6 \\
\hline Polygonum lapathyfolium & 3 & 39 & 2,0 \\
\hline Sambucus ebulus & 3 & 23 & 2,0 \\
\hline Echinochloa macrocarpa & 3 & 18 & 2,0 \\
\hline Setaria italica & 3 & 5 & 2,0 \\
\hline Vicia cracca & 2 & 14 & 1,3 \\
\hline Sambucus nigra & 2 & 4 & 1,3 \\
\hline Polygonum persicaria & 2 & 4 & 1,3 \\
\hline Arctium minus & 2 & 4 & 1,3 \\
\hline Atriplex rosea & 2 & 4 & 1,3 \\
\hline Polygonum orientale & 2 & 2 & 1,3 \\
\hline
\end{tabular}


1. táblázat (folytatás): A balkáni gerle táplálékának összetevői kis és közepes állománysürüségü helyeken, Magyarországon (n=149) (RÉKÁSI 1980)

Table 1 (cont.): Food composition of Eurasian Collared Dove at low and middling population density in Hungary ( $n=149)$ (RÉKÁSI 1980).

\begin{tabular}{lccc}
\hline Gyommagvak & $\begin{array}{c}\text { Eset } \\
\text { Presence }\end{array}$ & $\begin{array}{c}\text { Darabszám } \\
\text { Number }\end{array}$ & $\begin{array}{c}\text { Elöfordulási \% } \\
\text { Presence \% }\end{array}$ \\
\hline Chenopodium album & 1 & 121 & 0,6 \\
Corispermum nitidum & 1 & 12 & 0,6 \\
Ajuga laxmanni & 1 & 5 & 0,6 \\
Ajuga reptans & 1 & 5 & 0,6 \\
Veronica hederaefolia & 1 & 3 & 0,6 \\
Chenopodium vulvaria & 1 & 2 & 0,6 \\
Atriplex oblongifolia & 1 & 2 & 0,6 \\
Agrosthemma githago & 1 & 2 & 0,6 \\
Polygonum arenarium & 1 & 1 & 0,6 \\
Euphorbia helioscopia & 1 & 1 & 0,6 \\
Echinochloa hostii & 1 & 1 & 0,6 \\
Datura stramonium & 1 & 1 & \\
\hline Emészth etetlen any ag & & & \\
Indigestible material & & & \\
\hline Kavics/zúzókö Gastrolits & 145 & 4626 & \\
\hline
\end{tabular}

2. táblázat: A balkáni gerle táplálékának összetevői nagy állománykoncentráció mellett Magyarországon ( $\mathbf{n = 2 7 2 )}$ (RÉKÁSI 1980).

Table 2: Food composition of Eurasian Collared Dove at high population density in Hungary (n=149) (RÉKÁSI 1980).

\begin{tabular}{lccc}
\hline \multicolumn{1}{c}{$\begin{array}{c}\text { Táplálék összetevők } \\
\text { Food components }\end{array}$} & $\begin{array}{c}\text { Eset } \\
\text { Presence }\end{array}$ & $\begin{array}{c}\text { Darabszám } \\
\text { Number }\end{array}$ & $\begin{array}{c}\text { Elöfordulási \% } \\
\text { Presence \% }\end{array}$ \\
\hline Kultúr magvak & & & \\
Seeds of cultivated plants & 197 & 368 & 84,1 \\
\hline Helianthus annuus & 12 & 30 & 5,1 \\
Triticum aestivum & 11 & 15 & 4,7 \\
Zea mays & 9 & 15 & 3,8 \\
Vitis vinifera & 1 & 1 & 0,4 \\
Pisum sativum & & & \\
Gyommagvak & & & 22,6 \\
Seeds of weed plants & 53 & 433 & 13,6 \\
\hline Polygonum convolvulus & 32 & 335 & 9,4 \\
Setaria lutescens & 22 & 688 & 8,9 \\
Sambucus nigra & 21 & 161 & 8,9 \\
Vicia sp. & 21 & 140 & 5,5 \\
Polygonum aviculare & 13 & 76 & 4,2 \\
Polygonum lapathifolium & 10 & 38 & 3,4 \\
Convolvulus arvensis & 8 & 13 & 2,1 \\
Amaranthus retroflexus & 5 & 16 & 1,7 \\
Echinochloa crus galli & 27 & 1,7 \\
Chenopodium hybridum & 4 & 16 & 1,7 \\
Rubus caesius & 4 & & \\
Amaranthus blitoides & 4 & & \\
\hline
\end{tabular}


2. táblázat (folytatás): A balkáni gerle táplálékának összetevői nagy állomány koncentráció mellett Magyarországon ( $\mathrm{n}=\mathbf{2 7 2})$ (RÉKÁSI 1980).

Table 2 (cont.): Food composition of Eurasian Collared Dove at high population density in Hungary $(n=149)($ RÉKÁSI 1980).

\begin{tabular}{lccc}
\hline \multicolumn{1}{c}{$\begin{array}{c}\text { Táplálék összetevök } \\
\text { Food components }\end{array}$} & $\begin{array}{c}\text { Eset } \\
\text { Presence }\end{array}$ & $\begin{array}{c}\text { Darabszám } \\
\text { Number }\end{array}$ & $\begin{array}{c}\text { Elöfordulási \% } \\
\text { Presence \% }\end{array}$ \\
\hline $\begin{array}{l}\text { Gyommagvak } \\
\text { Seeds of weed plants }\end{array}$ & & \\
\hline $\begin{array}{l}\text { Chenopodium album } \\
\text { Stellaria media }\end{array}$ & 2 & 2 & 0,8 \\
Trifolium sp. & 1 & 37 & 0,4 \\
Amaranthus albus & 1 & 6 & 0,4 \\
\hline Emészthetetlen anyag Indigestible material & 1 & & 0,4 \\
\hline Kavics & 221 & 9566 & 94,4 \\
Agyag & 1 & 1 & 0,4 \\
Széndarab & 1 & 1 & 0,4 \\
\hline
\end{tabular}

3. táblázat: A balkáni gerle táplálékának összetevői a költési időszakban Magyarországon ( $\mathrm{n}=38)$ (RÉKÁSI 1980).

Table 3: Food composition of Eurasian Collared Dove in the breeding season in Hungary $(n=38)$ (RÉKÁSI 1980).

\begin{tabular}{|c|c|c|c|}
\hline $\begin{array}{l}\text { Táplálék összetevők } \\
\text { Food components }\end{array}$ & $\begin{array}{c}\text { Eset } \\
\text { Presence }\end{array}$ & $\begin{array}{l}\text { Darabszám } \\
\text { Number }\end{array}$ & $\begin{array}{l}\text { Elöfordulási \% } \\
\text { Presence \% }\end{array}$ \\
\hline \multicolumn{4}{|l|}{$\begin{array}{l}\text { Kultúrnövények magvai } \\
\text { Seeds of cultivated plants }\end{array}$} \\
\hline Helianthus annuus & 30 & 1555 & 78,9 \\
\hline Triticum aestivum & 8 & 360 & 21,0 \\
\hline Zea mays & 8 & 111 & 21,0 \\
\hline Vitis vinifera & 3 & 6 & 7,8 \\
\hline Hordeum sp. & 2 & 3 & 5,2 \\
\hline Secale sp. & 1 & 1 & 2,6 \\
\hline \multicolumn{4}{|c|}{ Gyommagvak Seeds of weed plants } \\
\hline Setaria lutescens & 13 & 903 & 34,2 \\
\hline Polygonum convolvulus & 11 & 101 & 28,9 \\
\hline Sambucus ebulus & 4 & 31 & 10,5 \\
\hline Vicia sp. & 2 & 3 & 5,2 \\
\hline Polygonum lapathifolium & 1 & 17 & 2,6 \\
\hline Amaranthus retroflexus & 1 & 9 & 2,6 \\
\hline Polygonum aviculare & 1 & 6 & 2,6 \\
\hline Cannabis sp. & 1 & 3 & 2,6 \\
\hline Convolvulus arvensis & 1 & 2 & 2,6 \\
\hline Amaranthus blitoides & 1 & 1 & 2,6 \\
\hline Setaria viridis & 1 & 1 & 2,6 \\
\hline Bifora sp. & 1 & 1 & 2,6 \\
\hline Echinochloa crus galli & 1 & 1 & 2,6 \\
\hline Bromus sp. & 1 & 1 & 2,6 \\
\hline \multicolumn{4}{|c|}{ Puhatestǘek (Mollusca) Molluscs } \\
\hline Pupilla muscorum & 1 & 1 & 2,6 \\
\hline Helicella obvia & 1 & 1 & 2,6 \\
\hline \multicolumn{4}{|c|}{ Emészthetetlen anyag Indigestible material } \\
\hline Kavics & 38 & 829 & 100,0 \\
\hline Homok & 23 & $\mathrm{x}$ & 60,5 \\
\hline
\end{tabular}




\subsection{ELTERJEDÉS}

A balkáni gerle indiai-afrikai faunaelem, politipikus faj. Eredeti elterjedési területe KisÁzsiától kiindulva Közép-Ázsián, Indián keresztül Hátsó-Indiáig terjedt. Ezen elterjedési területen belül 4 alfaját különíthetjük el.

A törzsalak, (1) a $S$. d. decaocto Kisázsiában, Közép-Keleten, Arábia É-i részén át K-en Afganisztánig, Pakisztánig, É-Indiáig, Nepalig és Assamig terjed. Betelepült Európába, betelepítették Kínába, Koreába és Japánba. A $S . \quad d$. stoloczkae Kirgíziában, DKKazahsztánban és ÉNy-Kínában honos. A $S$. $d$. intercedens D-Indiában és Sri-Lankán, a $S$. $d$. xanthocyclus pedig ÉNy-Burmában és a trópusi DK-Ázsiában fordul elő (GLUTZ \& BAUER, 1980; CRAMP, 1985).

Lassú terjeszkedése a 20. század első harmadában kezdődött, ami hamarosan robbanásszerüvé vált. Első magyarországi megfigyelése 1926-ban történt Tiszaugon (Szolnok megye)(BANKOVICS 1984), s az 1950-es évekre - a zárt erdőségek kivételével - gyakorlatilag hazánk minden területét belakta (1. térkép) (KEVE-KLEINER 1944; KEVE 1950, 1962). Tulajdonképpen Magyarországról indult meg Európát elfoglaló terjeszkedése (2. térkép). 1964-ben már Izlandon is kimutatták. Különösen eröteljes volt előnyomulása KeletEurópában (NowAK 1960), beleértve az egykori Szovjetunió európai területét is (BOZSKO 1976a; HENGEVELD 1997). Napjainkra elfoglalta teljes Európát (3-4. térkép).

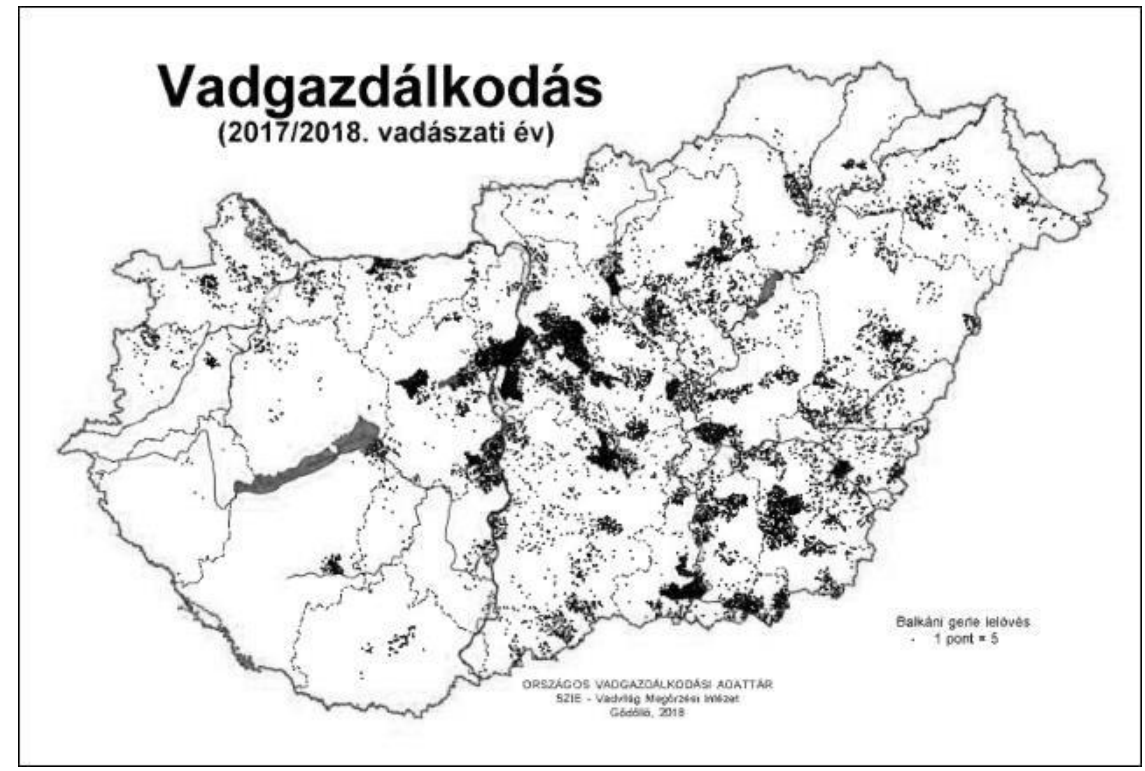

1. térkép: A balkáni gerle elterjedése Magyarországon a 2017/2018-as vadászati év terítéke alapján (OVA alapján)

Map 1: Distribution of Eurasian Collared Dove in Hungary on the basis of bag of the hunting season 2017/2018 (after National Game Management Database)

Magyarországon jelenleg is elsősorban az alacsonyabb erdősültségü területeken széltében elterjedt mindenütt, ahol fás vegetáció található (1. térkép). 


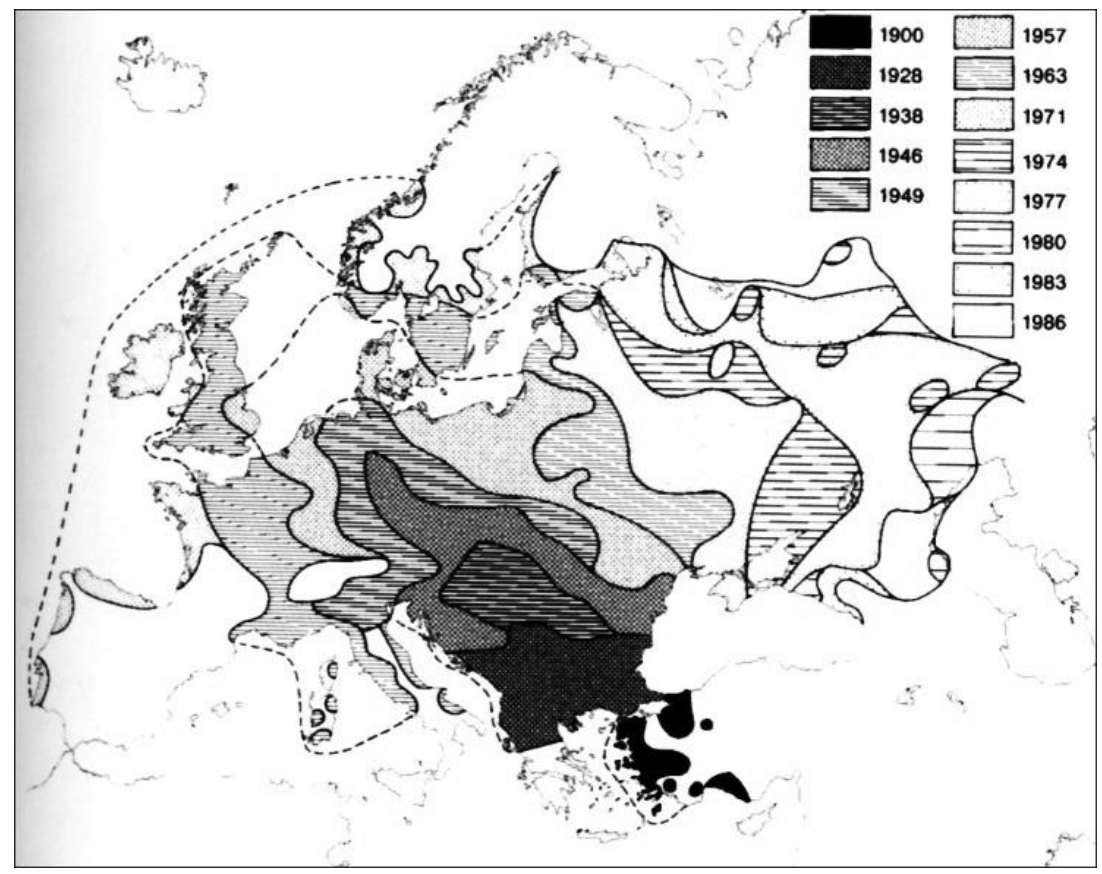

2. térkép: A balkáni gerle szétterjedése Európában a 20. század folyamán (HENGEVELD 1997)

Map 2: Expansion of Eurasian Collared Dove in Europe in the $20^{\text {th }}$ century (HENGEVELD 1997)

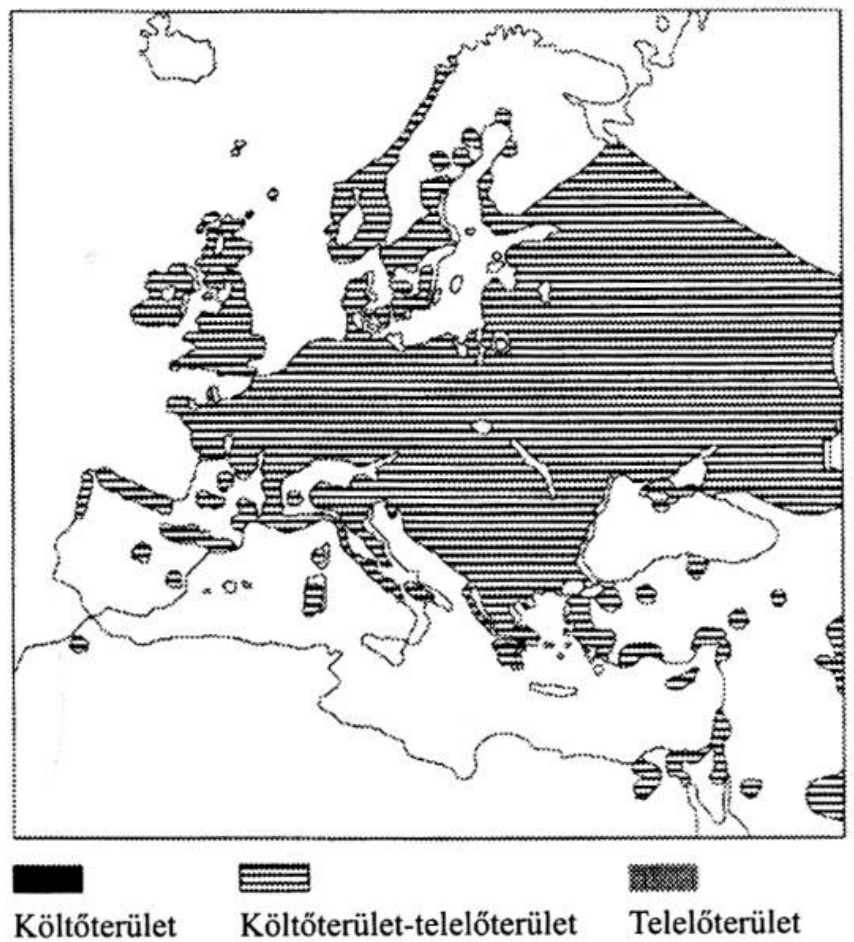

3. térkép: A balkáni gerle elterjedése Európában (JONSSON 1993)

Map 3: Distribution of Eurasian Collared Dove in Europe (JONSSON 1993) 


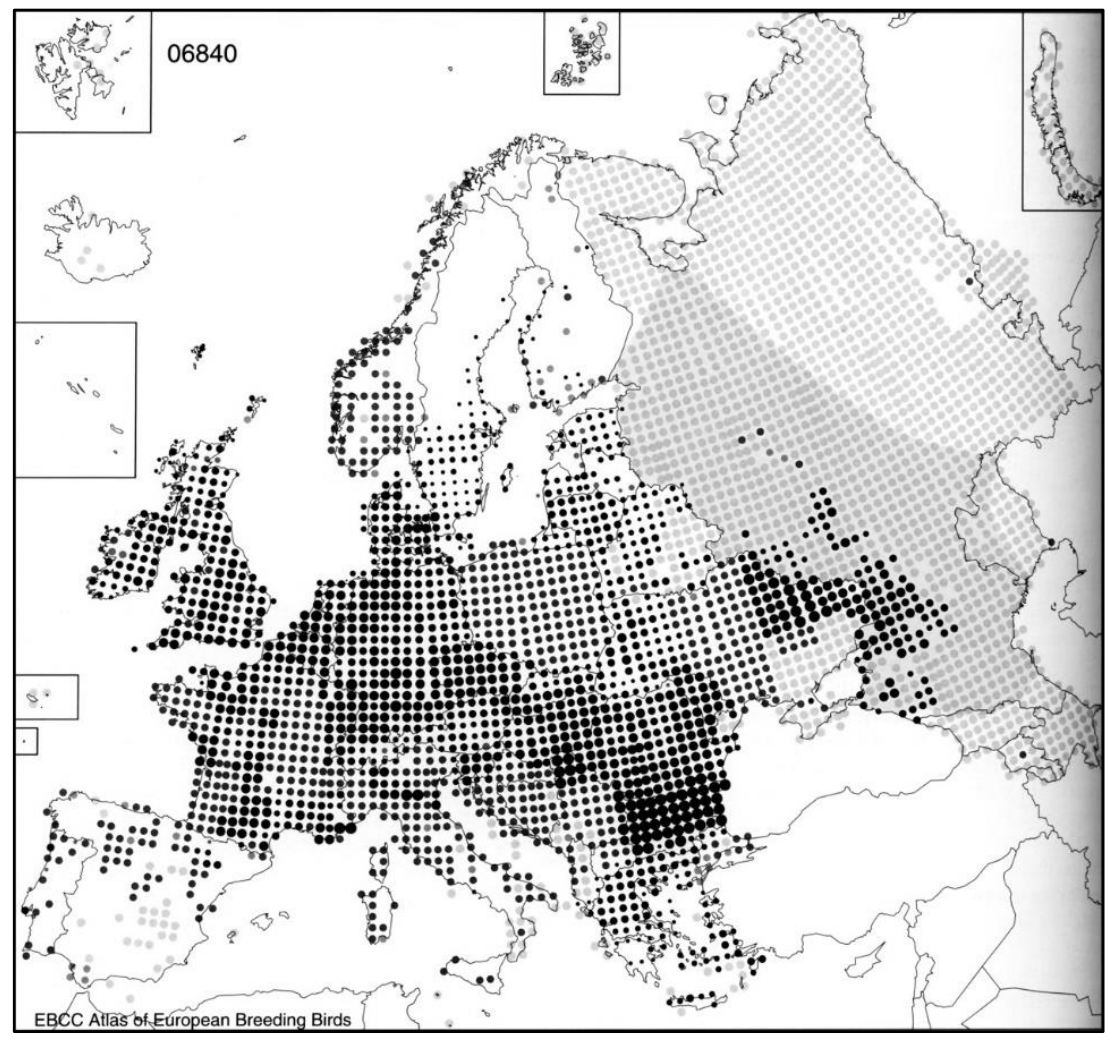

4. térkép: A balkáni gerle elterjedése Európában (HENGEVELD 1997) Map 4: Distribution of Eurasian Collared Dove in Europe (HENGEVELD 1997)

\subsection{MOZGÁS ÉS VÁNDORLÁS}

Eredeti, dél-ázsiai fészkelőhelyén állandó madár, csak a hegyvidéki fészkelőknél figyelhető meg az alacsonyabb térszínek felé irányuló elmozdulás. Az Európában megtelepülők ugyancsak állandó madárnak tekinthetők, legfeljebb kisebb téli migráció figyelhető meg, egyébként rendszeres mozgása csupán az éjszakázó és táplálkozó helyek között van (FARAGÓ 2001b).

Magyarországon jelölt balkáni gerléknek mindössze két $(0,2 \%)$ külföldi megkerülése van. Tornyosnémetiben (Borsod-Abaúj-Zemplén megye) jelölt madarakat néhány km-ről, Szlovákiából igazolták vissza. A legtávolabbi hazai megkerülés 204 km volt, a SzabolcsSzatmár-Bereg megyei Bökönyben fiatalon jelölt madarat csaknem három évvel később találták elhullva Szentendrén. A legidősebb madár a gyürüzést követően 8 év 5 hónap és 6 napot élt (visszafogva, elengedve) (FARAGÓ 2009).

\section{5. ÁllomÁNYNAGYSÁG}

Európai állománynagyságát az 1990-es években 4333 000-14 390000 példányban határozták meg (TUCKER \& HEATH, 1994). Az orosz populáció 10 000-100 000 pld-t, a török pedig 100 000-1 000000 pd közötti mennyiséget számlálhat (HENGEVELD 1997). A 2000-es években (BIRDLIFE INTERNATIONAL 2004) szerint mintegy 4700 000-11 000000 pár Európa költő balkáni gerle állománya. A környező országokból az alábbi állományadatok ismertek. Ausztria: 20 000-40 000 pár, Szlovákia: 40 000-80 000 pár, Ukrajna: 280 000-435 000 pár, Románia: 400 000-800 000 pár, Szerbia: 130 000-360 000 pár, Horvátország: 100 000150000 pár, Szlovénia: 40 000-60 000 pár (4. táblázat, 5. térkép). 
4. táblázat: A balkáni gerle állományának nagysága Európa országaiban (BIRDLIFE INTERNATIONAL, 2004)

Table 4: Eurasian Collared Dove populations in European countries (BIRDLIFE INTERNATIONAL, 2004)

\begin{tabular}{|c|c|c|c|c|}
\hline $\begin{array}{l}\text { Ország } \\
\text { Country }\end{array}$ & $\begin{array}{l}\text { Fészkelő állomány (pár } \\
\text { Breeding pop. size (pairs) }\end{array}$ & Év(ek) Year $(s)$ & $\begin{array}{l}\text { Trend } \\
\text { Trend }\end{array}$ & $\begin{array}{l}\text { Növ. \% } \\
\text { Mag. \% }\end{array}$ \\
\hline Albania & $5.000-10.000$ & 02 & $(+)$ & $(0-19)$ \\
\hline Andorra & $0-6$ & 02 & + & $\mathrm{N}$ \\
\hline Armenia & $150-300$ & $99-02$ & + & $20-29$ \\
\hline Austria & $(20.000-40.000)$ & $98-02$ & $(0)$ & $(0-19)$ \\
\hline Azerbaijan & $(10.000-100.000)$ & $96-00$ & $(+)$ & $(>80)$ \\
\hline Belarus & $4.500-7.000$ & $97-02$ & 0 & $0-19$ \\
\hline Belgium & $70.000-100.000$ & $01-02$ & + & $0-19$ \\
\hline Bosnia \&HG & Jelen/Present & $90-03$ & $?$ & - \\
\hline Bulgaria & $100.000-500.000$ & $96-02$ & - & $0-19$ \\
\hline Croatia & $(100.000-150.000)$ & 02 & (0) & $(0-19)$ \\
\hline Cyprus & $6.000-12.000$ & $98-02$ & + & $30-49$ \\
\hline Czech Rep. & $180.000-360.000$ & 00 & 0 & $0-9$ \\
\hline Denmark & $20.000-50.000$ & 00 & $(-)$ & $(10-19)$ \\
\hline Faroe Is. & $10-10$ & 95 & (0) & $(0-19)$ \\
\hline Estonia & $(400-800)$ & 98 & - & $20-29$ \\
\hline Finland & $100-150$ & $98-02$ & + & 20 \\
\hline France & $400.000-1.600 .000$ & $98-02$ & + & 100 \\
\hline Georgia & Jelen/Present & 03 & $?$ & - \\
\hline Germany & $270.000-440.000$ & $95-99$ & $(-)$ & $(20-29)$ \\
\hline Greece & $(10.000-50.000)$ & $95-00$ & (0) & $(0-19)$ \\
\hline Hungary & $160.000-220.000$ & $99-02$ & 0 & $0-19$ \\
\hline Rep. Ireland & $20.000-100.000$ & $88-91$ & 0 & $0-19$ \\
\hline Italy & $(300.000-500.000)$ & 03 & $(+)$ & $(10-19)$ \\
\hline Latvia & $200-500$ & $90-00$ & - & $0-19$ \\
\hline Liechtenstein & $5-10$ & $98-00$ & + & $0-19$ \\
\hline Lithuania & $(10.000-20.000)$ & $99-01$ & $(-)$ & $(20-29)$ \\
\hline Luxembourg & $200-300$ & 02 & - & $30-49$ \\
\hline Macedonia & $5.000-10.000$ & $90-00$ & - & $10-19$ \\
\hline Moldova & $40.000-80.000$ & $90-00$ & + & $30-49$ \\
\hline Netherlands & $50.000-100.000$ & $98-00$ & $\mathrm{~F}$ & 26 \\
\hline Norway & $500-3.000$ & $90-03$ & - & $20-29$ \\
\hline Poland & $200.000-400.000$ & $00-02$ & $(-)$ & $(0-19)$ \\
\hline Portugal & $(5.000-50.000)$ & 02 & $(+)$ & $(-)$ \\
\hline Romania & $(400.000-800.000)$ & $90-02$ & (0) & $(0-19)$ \\
\hline Russia & $(500.000-1.000 .000)$ & $90-00$ & + & $20-29$ \\
\hline Serbia \&MN & $130.000-360.000$ & $90-02$ & + & $10-19$ \\
\hline Slovakia & $40.000-80.000$ & $80-99$ & + & $20-29$ \\
\hline Slovenia & $40.000-60.000$ & 94 & (0) & $(0-19)$ \\
\hline Spain & $(20.000-100.000)$ & $98-02$ & + & $>80$ \\
\hline Canary Is. & $(1.000-2.500)$ & $97-03$ & + & $\mathrm{N}$ \\
\hline Sweden & $2.000-3.000$ & $99-00$ & - & $20-29$ \\
\hline Switzerland & $15.000-20.000$ & $93-96$ & 0 & $0-19$ \\
\hline Turkey & $(1.000 .000-3.000 .000)$ & 01 & (0) & $(0-19)$ \\
\hline Ukraine & $280.000-435.000$ & $90-00$ & - & $0-19$ \\
\hline UK & $298.000-298.000$ & 00 & + & 42 \\
\hline Gibraltar & $80-100$ & 00 & + & $\mathrm{N}$ \\
\hline Összes - Total & $4.700 .000-11.000 .000$ & $\begin{array}{l}\text { Trend: enyhe } \mathrm{r} \\
\text { Moderate increase }\end{array}$ & kedés & $\begin{array}{c}\text { Világállomány } \\
25-49 \%\end{array}$ \\
\hline
\end{tabular}




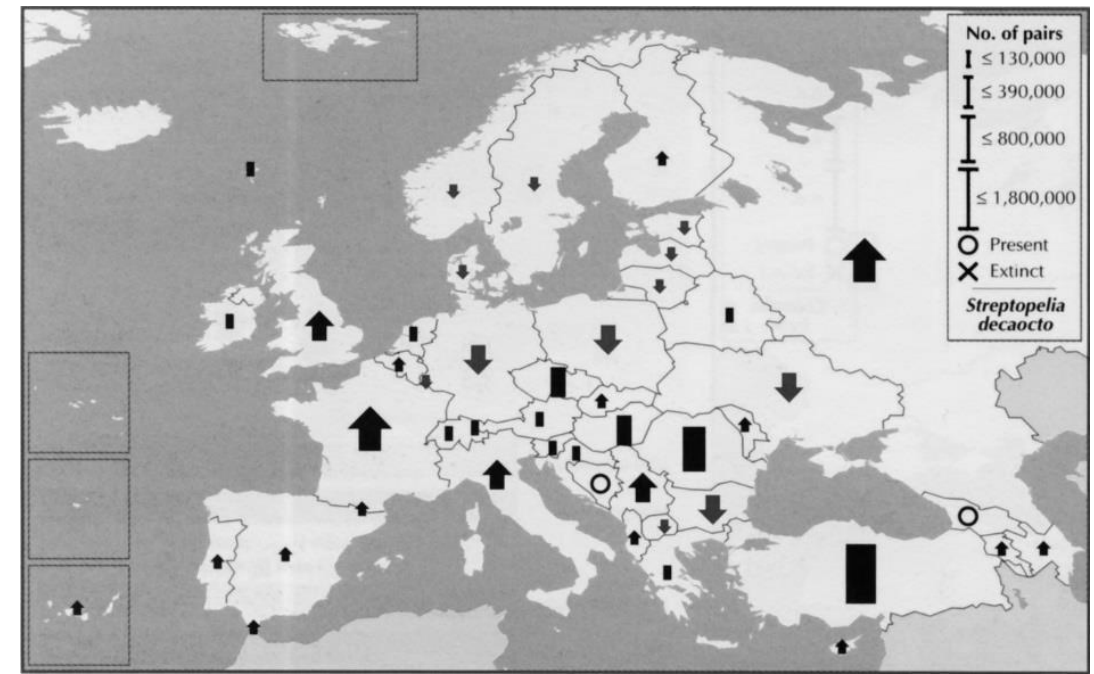

\section{5. térkép: A balkáni gerle állományok trendjei Európa egyes országaiban (BIRDLIFE INTERNATIONAL 2004)}

Map 5: Trends of Eurasian Collared Dove populations of different countries in Europe (BIRDLIFE INTERNATIONAL 2004)

Magyarország fészkelő balkáni gerle állománya az 1990-es években 100000 300000 pár lehetett (MAGYAR et al., 1998), ami a 2000-es évekre 160 000-220 000 párra csökkent (MME NOMENCLATOR BIZOTTSÁG 2008).

Számlált adataink néhány nagyvárosból vannak (BOZSKO \& JUHÁsZ 1984). Eszerint 1982-ben Nyíregyházán mintegy 12000 pld, Debrecenben 17000 pld, Egerben 770 pld, Győrben 3200 pld, Zalaegerszegen pedig 1000 pld volt a városban telelö állomány. Látható, hogy az alföldi nagyvárosok állományai sokkal magasabbak. Debrecen balkáni gerle populációjának vizsgálata az alábbi eredményeket hozta (BOZSKO \& JUHÁSZ, 1979; 1982). A fészkelési időszakban a populáció eloszlása egyenletes volt, ősztől tavaszig azonban a belvárosban tömörült. A fészkelési időszakban az állománysürüség a belvárosban 9,5-12,6 pár/ha, a parkokban 2,0-3,7 pár/ha, a lakótelepeken 3,6 pár/ha és a kertvárosban 1,4 pár/ha volt. Az éjszakázó helyek eloszlását a védelmi feltételek határozták meg. Nyáron csak a fiatalok és az éppen fészkelők tartózkodtak a belvárosban, szeptemberben és októberben a városi állomány 25-30\%-a, novemberben pedig 60-75\%-a éjszakázott ott. Az éjszakázó helyeken $(\mathrm{n}=30)$ az állománysürüség $3032 \mathrm{pld} / \mathrm{km}^{2}$ volt. A balkáni gerle állomány nagyságára bizonyos támpontot nyújt a vadlelövési statisztika is. Az 1970-es évek második felében évente átlagosan 60000 pd-t löttek. 1980-tól az éves teríték meghaladta a 100000 pd-t. A csúcsév 1984 volt, ekkor csaknem 204000 pd-t lőttek. Ez az adat nyilvánvalóan tartalmazza a törvénytelen nagyszámú vadgerle (Streptopelia turtur) lelövéseket is. A fokozott természetvédelmi hatósági munka eredményeként csökkent az illegális gerlelövés, így a korábbi maximumnak csak töredéke esik - igaz az utóbbi 20 évben emelkedő trenddel, 1995: 67428 pd, 2000: 49636 pd, 2005: 51899 pd, 2010: 53576 pd, 2011: 75558 pd, 2012: 88228 pd, 2013: 76432 pd, 2014: 67780 pd, 2015: 66785 pd, 2016: 48100 pd, 2017: 66336 pd (CSÁNYI 1999; 2001; CSÁNYI et al., 2005; 2010; 2012a; 2012b; 2014; 2015; 2016; 2017; CSÁNYI 2018).

Állományai jelentősen csökkentek, főként a Dunántúlon, de az alföldi területeken is. Elsősorban a nagyüzemi napraforgótáblák kárpótlás utáni nagymérvü visszaszorulása okozhatta állománycsökkenését az 1990-es évek második felében. Az egykori jelentős keletmagyarországi állomány is az 1990-es évek második fele óta folyamatosan csökken. Debrecenben az 1980-as évek maximumához képest a telelő állomány csaknem negyedére csökkent. 2007-ben 4300 téli éjszakázó madarat vettek számba. 2010-ben már csak 1500 
példány jelentette a telelö állományt. Nyíregyházán 2011-ben 8895, 2013-ban 7375 példányt sikerült felmérni. Debrecenben 2016-tól teljesen megszünt a téli csoportos éjszakázás, a városi telelö- és fészkelő állomány a töredékére zsugorodott össze (JuHÁsz \& VARGA 2017a). A városi területen élő balkáni gerlék diszpergálódva, páronként zártabb lombkoronájú vagy örökzöld fákon éjszakáznak. Az un. törzspárok territóriumaikat megtartva egész évben egy szűk területen tartózkodnak - amennyiben a táplálkozási lehetőségek biztosítottak (VARGA \& JUHÁSZ 2018).

A hazai állomány változásáról a fészkelési időszakra vonatkozóan a Mindennapi Madaraink Monitoring (MMM) program szolgál információkkal (2. ábra) (MME 2019). Az eredmények a fészkelési időszakban mérsékelt (2,20\%), állománynövekedést mutatnak 19992018 időszakára.

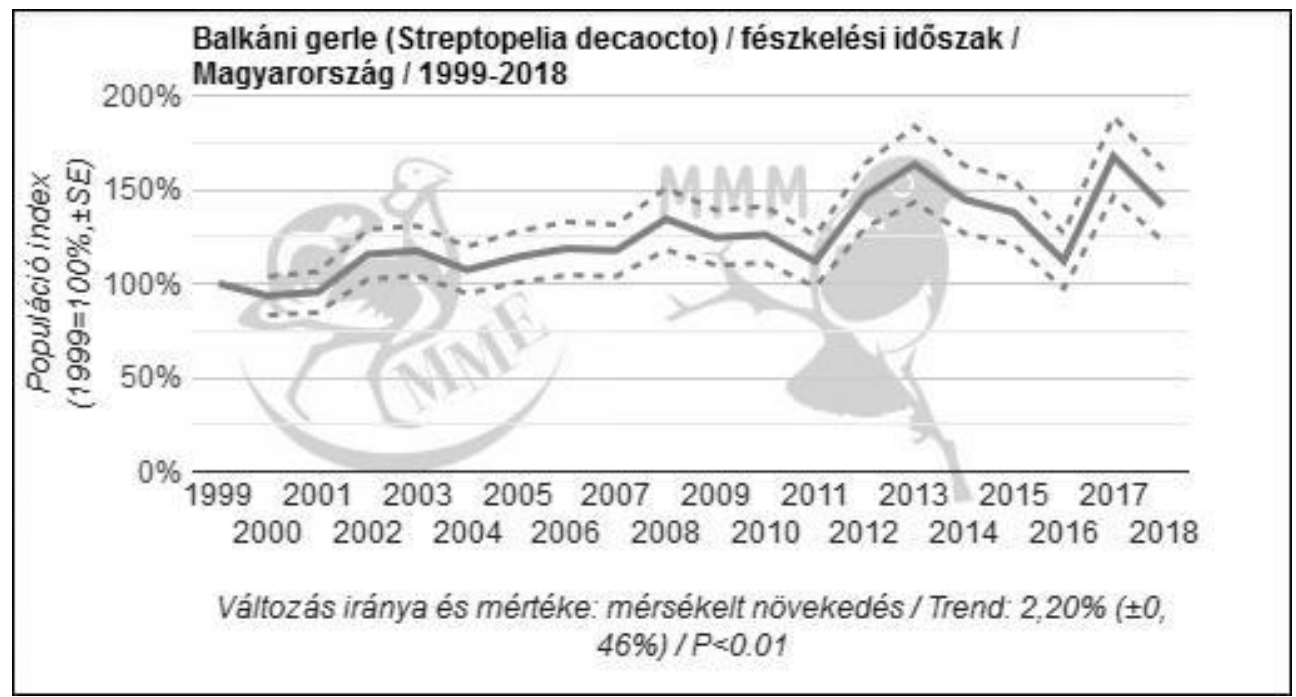

2. ábra: A balkáni gerle állomány alakulása Magyarországon az MMM fészkelési időszaki adatai alapján (MME 2019)

Figure 2: Dynamics of the Eurasian Collared Dove in Hungary, on the base of the date of MMM in the breeding season (MME 2020)

\subsection{TERMÉSZETES KORLÁTOZÓ TÉNYEZÖK}

\subsubsection{A populáció sürüségét befolyásoló elsődleges paraméterek}

A populációsűrüséget a termékenység, a halandóság, illetőleg a be- és elvándorlás határozza meg a balkáni gerle esetében is. A vadgazda feladata, hogy a termékenység növekedését elősegítő faktorokat erősítse, a halandóságot növelöket pedig csökkentse, vagy felszámolja. Az állomány megtartását a terület eltartóképességének növelésével lehet kiküszöbölni, amely az élőhelyek (táplálkozóhelyek) sokféleségének emelésével, valamint szerkezetük optimális kialakításával érhető el.

\section{A termékenységet}

(1) a táplálékforrás (állati, növényi) mennyisége és minősége, illetőleg

(2) a dúvadfajok sürüsége korlátozza.

Az ezzel összefüggő halandóságot

(1) a táplálékforrás mennyisége és minősége

(2) a dúvadfajok zsákmányolása és

(3) a vadászati hasznosítás mértéke

(4) a telelés során elszenvedett veszteségek határozzák meg. 


\subsubsection{A populáció sürüségét befolyásoló környezeti tényezők}

A balkáni gerle esetében befolyásolja, korlátozza beavatkozási lehetőségeinket, képességünket a faj településeken belüli nagy aránya.

A balkáni gerle populációk állománysürüségét is a populáció 4 elsődleges paraméterén (termékenység-halandóság illetve be- és elvándorlás) keresztül az élőhely szerkezete, a táplálékforrás kínálata, az időjárási tényezők és a predáció határozzák meg. A részben mezei környezetben fészkelö, vagy ott táplálkozó populációk esetében nem hagyható figyelmen kívül a mezőgazdasági technológiai folyamatok elsősorban megfelelő mennyiségü, egészséges táplálékforrást befolyásoló hatása (FARAGÓ 1997). Az urbánus környezetben megjelenő állomány legfontosabb populációszabályozója a területen élő predátorok közül a dolmányos varjú (Corvus cornix) és a szarka (Pica pica). Mindkét varjú faj erőteljes városi állománya a balkáni gerle fészkelési sikerét folyamatosan gátolja. Ezt támasztja alá az a megfigyelés, miszerint Debrecenben a dolmányos varjú városi állományának mintegy másfél évtized óta tartó folyamatos expanzív növekedése (KÖVÉR et all.) a balkáni gerle populáció csaknem teljes eltünését eredményezte. Fészekkamerás felvételek igazolták a dolmányos varjú tojás predációját (JUHÁSZ \& VARGA 2017a). Ezzel szemben Nyíregyházán gyakorlatilag nem mérhető a dolmányos varjú állomány, így ott a balkáni gerle állományának csökkenése kevésbé érezhető (JUHÁSZ \& VARGA 2017b).

1. A legfontosabb fészkelésre választott fás élőhelyek növényállományainak vertikális szerkezete alkalmas a fészek elrejtésére, a sokféle természetes és termesztett növény pedig, a fiókanevelés idején biztosít számukra megfelelö élőhely diverzitást.

2. A táplálkozó helyet kínáló mezei élettér szerkezete még viszonylag nagytáblás növénytermesztés mellett is, egész évben biztosítja a balkáni gerle életfeltételeit.

3. A fészkelöhelyek kiterjesztése, a településekre való betelepülés a szaporodás biztonságának növelését eredményezte.

4. A fészkelés és a fiókanevelés időszakában az élöhelyek (beleértve az agrár élöhelyek is) megfelelő mennyiségben és minőségben, gyakorlatilag korlátok nélkül kínálják a növényi eredetü táplálékot.

5. Az eltérő vetés idejü, tenyészidőszakú, s így különböző betakarítási idejü termesztett növénykultúrák táplálékkínálata részben kiegészíti, részben helyettesíti a visszaszoruló, vagy betakarított növények kínálta táplálékforrást.

6. A fészekaljakban predátorok, úgymint a varjúfélék, a macskabagoly (Strix aluco), a vörös mókus (Sciurus vulgaris), a nyest (Martes foina), a nyuszt (Martes martes) és a házi macska okozhatnak érzékeny veszteséget. A felnőtt madarak esetében a ragadozómadarak (pl. karvaly, héja, vándorsólyom) okozhatnak veszteséget (GLUTZ \& BAUER 1980).

7. Fészkelési időszakban kritikus lehet az emberi zavarás, mert a kotló madarak akár több órás távolmaradással reagálnak a zaklatásra, ami a kelés sikerességét rontja (GLUTZ \& BAUER 1980).

8. A költő-, pihenő- és telelőterületeken a kemikáliákkal kezelt növényzet, mint táplálék okozta megnövekedett halandóság (RÉKÁSI 1980 a csávázószereket említi).

9. Fontos kérdés az állomány egészségügyi helyzete, amely különösen települési környezetben ki van téve a nagyobb sürüségü házi és parlagi galambok által esetlegesen terjesztett betegségek (madártuberkulózis, galambhimlö, potenciálisan madárinfluenza stb.) mortalitást okozó és növelő hatásának.

JUHÁSZ (1996) az állománycsökkenést negatív hatások együttesére vezeti vissza: 
- a faj városi elöhelyein bekövetkező kedvezőtlen ökológiai változásokra (flóraváltozás, zaj és légszennyezés)

- kompetitív fajok állománynövekedése (főként házi galamb)

- a táplálékbázis elvesztése - különösen kemény teleken (lásd még BAUER \& BERTHOLD 1997)

- a természetes predátorainak (dolmányos varjú, karvaly, héja) állománynövekedése (lásd még BAUER \& BERTHOLD 1997)

- a táplálékkal bejutó nehézfémterhelés növekedése (lásd még RÉKÁSI 1980)

\subsection{A vadászati hasznosítás értékelése}

A balkáni gerle vadászati idényét az elmúlt negyedszázadban 1993-2012 közötti rendeletek (8/1993 FM; 30/1997 FM; 79/2004 FVM; 7/2010 FVM) augusztus 15-október 31 között adták meg. A 72/2012 (VII.24) VM Rendeletben vadászidényét augusztus 15-január 31 időszakában állapították meg. Napjainkban is ez a terminus az érvényes.

Magyarországon kevesen vadásszák, bár károkozása miatt kárelhárító vadászat nélkülözhetetlenné válhat. Hagyománya sem nagy a galambvadászatnak, szemben Európa nyugati felével. Vadászterületeinken sok esetben külföldi vendégvadászok lövik, emiatt gazdasági jelentősége elhanyagolható. Az elmúlt években éves terítéke 1995: 67428 pd, 2000: 49636 pd, 2005: 51899 pd, 2010: 53576 pd, 2011: 75558 pd, 2012: 88228 pd, 2013: 76432 pd, 2014: 67780 pd, 2015: 66785 pd, 2016: 48100 pd, 2017: 66336 pd (CsÁNYI, 1999; 2000; 2001; CSÁNYI et al., 2005; 2010; 2012a; 2012b; 2014; 2015; 2016; 2017; CsÁNYI 2018) (5-6. táblázat; 3. ábra).

5. táblázat: A balkáni gerle terítékének megyénkénti alakulása Magyarországon 1995-2005 (OVA alapján)

Table 5: Eurasian Collared Dove bags in Hungarian counties in the period 1995-2005 (based on the NATIONAL MANAGEMENT DATABASE)

\begin{tabular}{|l|c|c|c|c|c|c|c|c|c|c|c|}
\hline Megye - County & $\mathbf{1 9 9 5}$ & $\mathbf{1 9 9 6}$ & $\mathbf{1 9 9 7}$ & $\mathbf{1 9 9 8}$ & $\mathbf{1 9 9 9}$ & $\mathbf{2 0 0 0}$ & $\mathbf{2 0 0 1}$ & $\mathbf{2 0 0 2}$ & $\mathbf{2 0 0 3}$ & $\mathbf{2 0 0 4}$ & $\mathbf{2 0 0 5}$ \\
\hline Baranya & 681 & 447 & 1168 & 1766 & 557 & 647 & 447 & 235 & 693 & 347 & 153 \\
\hline Bács-Kiskun & 10235 & 7240 & 9651 & 2508 & 4319 & 6069 & 4498 & 7985 & 6387 & 5025 & 4508 \\
\hline Békés & 12704 & 7674 & 4317 & 3978 & 3818 & 5373 & 7288 & 8205 & 7021 & 4531 & 6324 \\
\hline Borsod-Abaúj-Zemplén & 2445 & 1700 & 260 & 832 & 162 & 1894 & 2246 & 2233 & 2756 & 3344 & 1975 \\
\hline Csongrád & 6072 & 8466 & 2158 & 2297 & 2765 & 4022 & 4982 & 5692 & 6959 & 6521 & 5560 \\
\hline Fejér & 6781 & 5281 & 3310 & 3655 & 4534 & 4905 & 3824 & 4197 & 4990 & 3539 & 3240 \\
\hline Györ-Moson-Sopron & 588 & 501 & 941 & 1316 & 1020 & 465 & 1142 & 1208 & 1641 & 2316 & 1971 \\
\hline Hajdú-Bihar & 1661 & 914 & 506 & 328 & 440 & 592 & 479 & 546 & 1757 & 1424 & 1325 \\
\hline Heves & 1130 & 936 & 612 & 1005 & 932 & 1211 & 739 & 2394 & 3905 & 3252 & 3143 \\
\hline Komárom-Esztergom & 2643 & 3371 & 1871 & 648 & 670 & 2501 & 775 & 925 & 503 & 527 & 960 \\
\hline Nógrád & 472 & 319 & 84 & 77 & 103 & 102 & 27 & 124 & 467 & 407 & 344 \\
\hline Pest & 10608 & 9033 & 10048 & 15926 & 14397 & 18848 & 18330 & 23403 & 25167 & 17960 & 14314 \\
\hline Somogy & 1101 & 1046 & 845 & 589 & 783 & 400 & 348 & 429 & 388 & 390 & 254 \\
\hline Szabolcs-Szatmár-Bereg & 1622 & 2843 & 980 & 117 & 446 & 629 & 381 & 700 & 890 & 738 & 550 \\
\hline Jász-Nagykun-Szolnok & 6787 & 2566 & 2637 & 1548 & 724 & 1042 & 4177 & 5083 & 5633 & 6845 & 5983 \\
\hline Tolna & 1113 & 1078 & 1093 & 342 & 147 & 436 & 814 & 483 & 1206 & 555 & 984 \\
\hline Vas & 141 & 195 & 208 & 271 & 222 & 99 & 89 & 144 & 158 & 104 & 56 \\
\hline Veszprém & 366 & 334 & 205 & 202 & 129 & 395 & 104 & 68 & 51 & 115 & 252 \\
\hline Zala & 278 & 110 & 122 & 50 & 48 & 6 & 28 & 1 & 7 & 2 & 3 \\
\hline Magyarország összesen - total & $\mathbf{6 7 4 2 8}$ & $\mathbf{5 4 0 5 4}$ & $\mathbf{4 1 0 1 6}$ & $\mathbf{3 7 4 5 5}$ & $\mathbf{3 6 2 1 6}$ & $\mathbf{4 9 6 3 6}$ & $\mathbf{5 0 7 1 8}$ & $\mathbf{6 4 0 5 5}$ & $\mathbf{7 0 5 7 9}$ & $\mathbf{5 7 9 4 2}$ & $\mathbf{5 1 8 9 9}$ \\
\hline
\end{tabular}


6. táblázat: A balkáni gerle terítékének megyénkénti alakulása Magyarországon 2006-2017 (OVA alapján)

Table 6: Eurasian Collared Dove bags in Hungarian counties in the period 2006-2017 (based on the NATIONAL MANAGEMENT DATABASE)

\begin{tabular}{|l|c|c|c|c|c|c|c|c|c|c|c|c|}
\hline \multicolumn{1}{|c|}{ Megye -County } & $\mathbf{2 0 0 6}$ & $\mathbf{2 0 0 7}$ & $\mathbf{2 0 0 8}$ & $\mathbf{2 0 0 9}$ & $\mathbf{2 0 1 0}$ & $\mathbf{2 0 1 1}$ & $\mathbf{2 0 1 2}$ & $\mathbf{2 0 1 3}$ & $\mathbf{2 0 1 4}$ & $\mathbf{2 0 1 5}$ & $\mathbf{2 0 1 6}$ & $\mathbf{2 0 1 7}$ \\
\hline Baranya & 166 & 530 & 417 & 535 & 644 & 510 & 589 & 449 & 590 & 486 & 220 & 261 \\
\hline Bács-Kiskun & 4843 & 7224 & 6172 & 8200 & 4735 & 5145 & 10087 & 6140 & 5488 & 6587 & 4182 & 6597 \\
\hline Békés & 6305 & 10213 & 8194 & 11959 & 8576 & 19329 & 16364 & 10650 & 9252 & 7532 & 6470 & 9090 \\
\hline Borsod-Abaúj-Zemplén & 1263 & 2738 & 2252 & 2923 & 1033 & 2146 & 1456 & 1860 & 2212 & 1718 & 1131 & 1612 \\
\hline Csongrád & 4945 & 10934 & 8261 & 9023 & 7857 & 9014 & 10548 & 6632 & 6418 & 7413 & 5080 & 7602 \\
\hline Fejér & 2847 & 4368 & 3177 & 4615 & 3536 & 3813 & 3938 & 4739 & 4057 & 3855 & 3832 & 4925 \\
\hline Györ-Moson-Sopron & 2392 & 2388 & 3157 & 4663 & 2957 & 4019 & 3394 & 3613 & 3863 & 4338 & 2370 & 2032 \\
\hline Hajdú-Bihar & 1719 & 6170 & 4276 & 2923 & 3115 & 3812 & 3323 & 2778 & 3122 & 3310 & 1621 & 3014 \\
\hline Heves & 2549 & 3232 & 3300 & 2866 & 1571 & 1321 & 3375 & 2136 & 3319 & 2953 & 3727 & 3387 \\
\hline Komárom-Esztergom & 506 & 1902 & 1627 & 1920 & 1092 & 1200 & 1074 & 941 & 1362 & 1421 & 649 & 1147 \\
\hline Nógrád & 132 & 285 & 451 & 312 & 195 & 214 & 384 & 627 & 531 & 441 & 474 & 333 \\
\hline Pest & 11678 & 17854 & 13086 & 16109 & 10225 & 14258 & 21227 & 24392 & 17565 & 17622 & 11785 & 16271 \\
\hline Somogy & 227 & 184 & 185 & 264 & 550 & 422 & 203 & 523 & 178 & 146 & 969 & 831 \\
\hline Szabolcs-Szatmár-Bereg & 597 & 2229 & 1313 & 1257 & 956 & 2233 & 2587 & 2646 & 2891 & 2173 & 1311 & 1739 \\
\hline Jász-Nagykun-Szolnok & 5424 & 11084 & 8369 & 9091 & 5638 & 6814 & 8085 & 5874 & 5027 & 4959 & 2832 & 5301 \\
\hline Tolna & 637 & 625 & 1221 & 1497 & 164 & 682 & 640 & 1431 & 893 & 787 & 256 & 1041 \\
\hline Vas & 142 & 183 & 315 & 280 & 461 & 293 & 510 & 529 & 483 & 494 & 650 & 702 \\
\hline Veszprém & 212 & 396 & 233 & 198 & 230 & 291 & 408 & 406 & 493 & 465 & 504 & 394 \\
\hline Zala & 5 & 55 & 40 & 9 & 41 & 42 & 36 & 66 & 36 & 85 & 37 & 57 \\
\hline Magyarország összesen -total & $\mathbf{4 6 5 8 9}$ & $\mathbf{8 2 5 9 4}$ & $\mathbf{6 6 0 4 6}$ & $\mathbf{7 8 6 4 4}$ & $\mathbf{5 3 5 7 6}$ & $\mathbf{7 5 5 5 8}$ & $\mathbf{8 8 2 2 8}$ & $\mathbf{7 6 4 3 2}$ & $\mathbf{6 7 7 8 0}$ & $\mathbf{6 6 7 8 5}$ & $\mathbf{4 8 1 0 0}$ & $\mathbf{6 6 3 3 6}$ \\
\hline
\end{tabular}

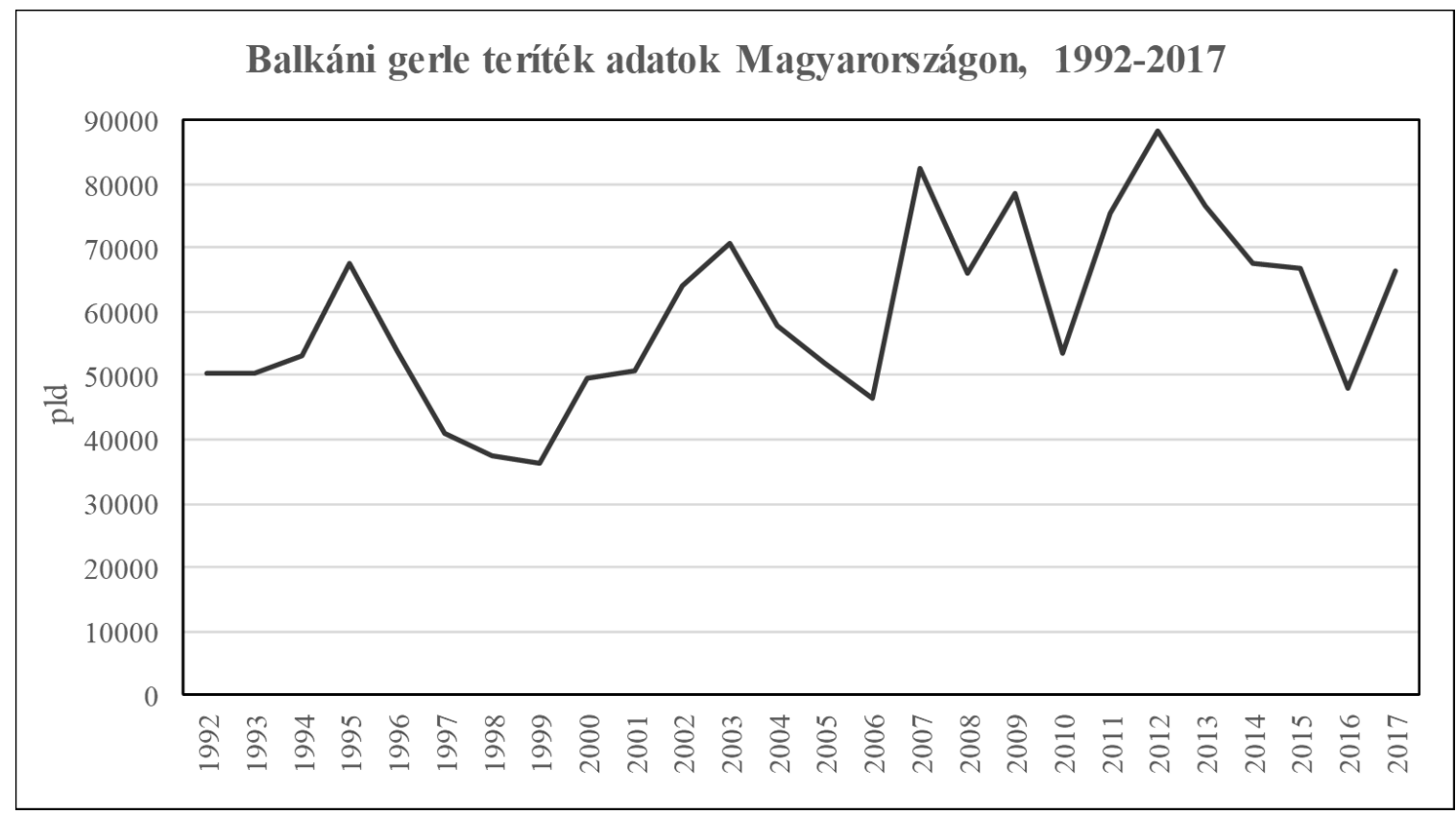

\section{3. ábra: A balkáni gerle teríték alakulása 1992-2017 között Magyarországon (OVA alapján)}

Figure 3: Eurasian Collared Dove bags between 1992 and 2017 in Hungary (based on the NATIONAL GAME MANAGEMENT DATABASE)

A kistestü (mintegy 200 gramm testtömegü), gyors röptü, nehéz célt mutató balkáni gerle ,puha madár”, azaz nagy magasságból is leszólítható. A vadászat helye mindenek előtt a napraforgó tábla, tarló, de magtárak környéke is lehet. Nem érzékeny a takarás hiányára (persze azért nem hátrány, ha van), ezt a módot mégis lesvadászatnak tekintjük. A 
gerlevadászatot is eredményesebbé tehetjük csaliállatok és felpeckelt madarak alkalmazásával. Vadászatuk során két fontos szabályt kell szigorúan betartani és betartatni: egyik a településtől való szabályos vadászati távolság, a másik pedig a védett vadgerle mindenek feletti kímélete! Gerlézésre a 12-es (2,5 mm-es sörétszem átmérőjü) patron a legalkalmasabb, de jó a 10-es kaliber is (külföldön ún. madársöréttel töltött lőszert is használnak). Bár nincs napi teríték határa, s egy-egy jó helyen akár több százat is löhet egy rutinos puskás, mégis a mai világban nem feltétlenül kell erre törekedni. Az élmény, a „korlátlan lehetőség” ne vegye el tisztánlátásunkat, próbáljunk meg magunknak korlátokat állítani. E faj esetében a „hajtás” lehetőségével is meg lehet próbálkozni, pontosabba a leálló puskások felé lehet mozgatni a tarlón, vagy a napraforgó táblán táplálkozó madarakat (FARAGÓ 2006).

\section{CSELEKVÉSI TERV}

\subsection{CÉLKITÜZÉS}

A balkáni gerle a magyar vadgazdálkodásban, apróvad-gazdálkodásban viszonylag kis jelentöséggel bír. Bár terítéke az utóbbi évtizedben csökkent, még így is meghaladja az évenkénti 60000 példányt. A teríték-csökkenés az állomány MME Mindennapi Madaraink Monitoring szerint szerény mértékü $(2 \%)$ növekedésével párhuzamosan történt, aminek két üzenete van.

Az egyik, hogy az állomány növekedése a vadászati nyomás jelentős csökkenése mellett következett be, tehát a vadászat érdemben befolyásolhatja a magyar balkáni gerle népesség helyzetét.

A másik üzenet, hogy a bölcs hasznosítás lehetősége alapján az állomány megfelelö mértékben hasznosított, azaz a vadászati nyomás e szintje fenntartható, amivel egy izgalmas vadászati lehetőséget lehet kihasználni.

Fentiek alapján a mezei területek apróvad vadászati lehetôségeinek beszükülése okán a balkáni gerle vadászat augusztus-október hónapokban alternativ mezei vadászati lehetöséget kínál a magyar (és külföldi) vadászoknak. A magyar állomány a jelenlegi hasznosítási mértéket fenntartható módon elviseli!

\subsection{FELADATOK}

\subsection{1. Élőhelygazdálkodás}

A fás élőhelyek (fészkelőhelyek) védelme a jelenlegi gyakorlatnál nem kíván határozottabb beavatkozást. A mezei területeken, különösen erösávok, mezei fásítások esetében a cserjeszint kímélete révén valósulhat meg a fészkelőhelyek biztosítása. Ugyanakkor laza szerkezetü erdősávoknál és fás vegetációtól mentes területeken a cserje alátelepítés, vagy cserje telepítés a galamb-félék, így a balkáni gerle fészkelését segítő élőhelyfejlesztés leghatékonyabb módja. További segítséget jelent a galambfajoknak mesterséges fészekalapok (pl. kosarak) kihelyezése akár a lombkorona, akár a cserjeszintbe (Az el nem foglalt fészekalapok fészkelési lehetőséget biztosíthatnak más, védett fajoknak, mint vörös vércse, kékvércse, erdei fülesbagoly stb.). A felnőtt és kirepült madarak táplálkozását segíti a nyári tarlók minél hosszabb idejü megtartása, a terület bizonyos részein. Ez az eljárás egyébként a vadászatot is segítheti augusztus közepétől. Ennek megvalósítása a mai mezőgazdálkodási gyakorlatban nehézséget is jelent, mert a tarlók mielőbbi hántásának gyakorlata a vadvédelem és a vadászat érdekeivel ellentétes. Nagyfokú megértésre és együttmüködési készségre van szükség (FARAGÓ 1997). 
Jelentőség: Nagy (8-10)

Hatékonyság: Nagy (8)

Érintett állománynagyság: $100 \%$

Ütemezés: Fészkelési időszak

Felelős: Vadászati hatóságok, tájegységi fővadászok

Együttmüködő: OMVV, OMVK, vadgazdálkodók, erdészeti hatóság, természetvédelmi hatóság, nemzeti park, mezőgazdálkodók, mezőgazdasági érdekképviseleti szervek,.

\subsection{2. Állományhasznosítás lehetősége és jogi keretei}

A balkáni gerle Non-SPEC, Európában stabil állományú (S) faj (TUCKER \& HEATH, 1994). A Berni Egyezmény III. Mellékletében és az EU Madárvédelmi Irányelvek II/2. Mellékletében szerepel. Szerte Európában, így Magyarországon is vadászható faj, amelyre vadászidény került megállapításra. Napi terítéklimitje nincs, itthon vadgazdálkodási értéke 10000 Ft.

\subsubsection{Az állományhasznosítás ideje}

1993-ig egész évben vadászható volt, azt követően - napjainkig: augusztus 15. - január 31 közötti időszakban, azaz 170 nap.

\subsubsection{A hasznosítás eszköztára}

Vadászatára a vadászati idényben szinte kizárólagosan a húzáson történö lesvadászat kínálkozik (leírását lásd 1.7. fejezet). A müanyag csalimadarak alkalmazásának elsajátítása növelheti a hasznosítás eredményességét. E módszer megismertetése a vadászokkal több módon lehetséges.

Magyarországon sörétes fegyverrel való vadászatára van mód. Európa több országában dívik a légfegyveres les vadászat. A magyar légfegyver-használati korlátok (max. 4,5 mm és 7 Joul) azonban ezt a vadászati módot országunk területén nem teszik lehetővé.

Jelentőség: Közepes (6)

Hatékonyság: Magas (9-10)

Ütemezés: évente augusztus 15 . és január 31. között

Felelős: FM Erdészeti és Vadgazdálkodási Főosztály, megyei vadászati hatóságok

Együttmüködők: vadgazdálkodók, Országos Magyar Vadászati Védegylet

\subsubsection{Tanácsadás vad- és erdőgazdálkodók, természetvédők számára}

A hivatásos vadász valamint természetvédelmi őri továbbképzéseken időszakonként meg kell ismertetni a gazdálkodókkal és területkezelőkkel a galamb-félék tényleges gazdálkodási jelentőségét, a vad védelmi feladatokat és a fenntartható vadászatában rejlő gazdálkodási lehetőségeket és korlátokat, Európa más országaiban alkalmazott, nálunk is jogszerüen alkalmazható vadászati módokat.

Jelentőség: Közepes (6)

Hatékonyság: Közepes (6)

Ütemezés: Költési és fiókanevelési időszak előtt, szükség szerint ismételve

Felelős: megyei vadászati hatóságok, Országos Magyar Vadász Kamara

Együttműködők: vadgazdálkodók, erdőgazdálkodók, természetvédelem 


\subsubsection{Oktatás és továbbképzés}

A balkáni gerle (általában a vadászható galamb-félék) vadászatára/hasznosítására vonatkozó ismeretek oktatása és annak folyamatos aktualizálása fontos az alap-, közép- és felsőfokú vadgazdálkodási (és természetvédelmi) szakemberképzésben. Az intézmények tananyagai, tankönyvei és jegyzetei tartalmazzák a vadászat elméleti és gyakorlati ismeretanyagát. A szakemberek továbbképzései során esetenként fel kell frissíteni fenntartható vadászatának lehetőségeit, módszereit és eredményeit.

Jelentőség: Magas (8-10)

Hatékonyság: Közepes (6)

Ütemezés: Folyamatosan

Felelös: OMVV, OMVK országos és megyei területi szervezetei, SoE-EMK Vadgazdálkodási és Gerinces Állattani Intézet

Együttmüködő: szakirányú képzést folytató alap-, közép- és felsőfokú oktatási intézmények

\subsubsection{Kutatás és monitoring}

A kutatásnak a faj hazai jobb megismerését kell szolgálnia. Ezek főbb elemei a következők:

- Fészkelö populáció diszperziója, szaporodási viszonyai

- Táplálkozása megváltozott körülmények között

- Élőhely-monitoring (fészkelőhely, táplálkozóhely)

- Telelési viszonyainak vizsgálata (pl. csapatképzés)

- Predáció hatásainak vizsgálata lakott területeken

Jelentőség: Közepes (6)

Hatékonyság: Közepes (6)

Ütemezés: Folyamatosan

Felelös: SoE-EMK Vadgazdálkodási és Gerinces Állattani Intézet

Együttmüködő: más felsőoktatási intézmények, vadgazdálkodók, Magyar Madártani és Természetvédelmi Egyesület

\subsubsection{Kommunikáció és nyilvánosság}

\subsubsection{Kommunikáció az érintett hatóságokkal, szervezetekkel}

A galamb-félék (benne a balkáni gerle) fenntartható hasznosításának érdekében a vadgazdálkodóknak jó kapcsolatokat kell kialakítani valamennyi, annak feltételeit elősegítő hatósággal:

- megyei vadászati hatóságok

- FM Erdészeti és Vadgazdálkodási Főosztály

- NÉBIH

- természetvédelemért felelős hatóságok/szervezetek

Jelentőség: Magas (8-10)

Hatékonyság: Jó (8)

Ütemezés: Folyamatosan

Felelős: FM Erdészeti és Vadgazdálkodási Főosztály 


\subsubsection{Kommunikáció a nagyközönséggel}

Szükséges rendszerességgel tájékoztatni kell a nagyközönséget a balkáni gerle - elsősorban károkozásából fakadó - hasznosítási szükségességéről, lehetőségéről és helyzetéről.

Különösen fontos a nagyközönséggel megismertetni az írott és elektronikus médián keresztül a vadászat szerepét, lehetőségeit és szabályozottságát. A kommunikáció súlyát növelik annak állatvédelmi vonzatai. Kiemelt jelentősége van a helyi médiafelületeken keresztüli tájékoztatásnak.

Jelentőség: Közepes (7)

Hatékonyság: Közepes (6)

Ütemezés: Aktualitások figyelembe vételével, évente ismételve

Felelös: Földművelésügyi Minisztérium, megyei Kormányhivatalok, OMVV, OMVK, SoEEMK Vadgazdálkodási és Gerinces Állattani Intézet, Magyar Madártani és Természetvédelmi Egyesület

\subsubsection{Felülvizsgálat}

A „Balkáni Gerle Kezelési Terv” megvalósítását évente, illetve szükség szerint áttekinti az Országos Vadgazdálkodási Tanács, és állásfoglalása alapján értékeli az AM Erdészeti és Vadgazdálkodási Főosztálya, amely azután - ha a helyzet úgy kívánja - meghozza a szükséges intézkedéseket.

\section{3. ÖSSZEFOGLALÁS}

\section{1. ÁLLOMÁNYSZABÁLYOZÁSI HELYZET}

A balkáni gerle becsült fészkelő állománynagysága az 1990-es években 100 000-300 000 pár lehetett (MAGYAR et al., 1998), ami a 2000-es évekre 160 000-220 000 párra csökkent (MME NOMENCLATOR BIZOTTSÁG 2008). A hazai állomány változásáról a fészkelési időszakra vonatkozóan a Mindennapi Madaraink Monitoring (MMM) program szolgál információkkal. Az eredmények gyenge állománynövekedést mutatnak 1999-2018 időszakára (MME 2019). Az elmúlt években éves terítéke - csökkenést mutatva - mintegy 60000 példány, tehát fenntartható mértékben hasznosított, amit a gyengén növekvő állományindex is igazol.

\subsection{KEZELÉSI PRIORITÁS}

A balkáni gerle, mint kisrészben erdei és mezei, nagyrészt urbánus környezethez kötődő madárfaj, a vadgazdálkodási intézkedések tekintetében nem bír különösebb prioritással, ugyanakkor - különösen a fogyó vadászati lehetöségeket kínáló mezei területeken megjelenési mennyiségével arányos, emeltebb prioritást érdemelhet.

\subsection{CÉLOK}

A vadászat érdemben nem befolyásolja a magyar balkáni gerle népesség helyzetét. A hasznosítás mértéke arányos a populáció nagyságával, kínálatával.

A mezei területek apróvad vadászati lehetőségeinek beszükülése okán a balkáni gerle vadászat augusztus-október hónapokban alternatív lehetőséget kínál a magyar (és külföldi) vadászoknak. 


\section{4. ÁTFOGÓ KEZELÉSI POLITIKA}

Prioritás lehet a vadászati lehetőségek emelt szintű kihasználása, régi vadászati módszerek felelevenítése és új vadászati módszerek bevezetése, a fenntarthatóság biztosításával.

\subsection{CSELEKVÉSI TERV}

\section{1. Élőhely-gazdálkodás}

C1.1. A fészkelőhelyek kímélete, fennmaradásuk elősegítése a leghatékonyabb élőhelygazdálkodási tevékenység

Nagy jelentöségü, hatékony. Felelös szervezet: megyei vadászati hatóságok, OMVV megyei szervezetei, erdészeti hatóságok

C.1.2. Cserjeszint alátelepítés, amely fészkelő helyet biztosít a balkáni gerle számára Nagy jelentöségü, hatékony. Felelös szervezet: megyei vadászati hatóságok, OMVV megyei szervezetei, erdészeti hatóságok

C.1.3. Nyári tarlók egy részének megtartása, táplálkozóhely biztosítása.

Nagy jelentőségü, hatékony. Felelös szervezet: megyei vadászati hatóságok, OMVV megyei szervezetei, falugazdászok

\section{Politika és jogalkotás}

C.2.1. Biztosítani kell az erdősávok, mezei fásítások védelmének és telepítésének jogi és gazdasági feltételeit.

Nagy jelentőségö, hatékony. Felelös szervezet: AM Erdészeti és vadgazdálkodási Föosztály

\section{Tanácsadás, oktatás}

C 3.1. A hivatásos vadász és természetvédelmi ör továbbképzéseken meg kell ismertetni a gazdálkodókkal a balkáni gerle tényleges vadgazdálkodási jelentőségét, lehetőségeit, a jó gyakorlatot.

Nagy fontosságú, nagy hatékonyságú. Felelös: OMVV, OMVK országos és megyei területi szervezetei, SoE-EMK Vadgazdálkodási és Gerinces Állattani Intézet.

\section{Kutatás és monitoring}

C.4.1. A kutatásnak a faj hazai jobb megismerését kell szolgálnia. Ezek főbb elemei a következők:

- Fészkelő populáció diszperziója, szaporodási viszonyai

- Táplálkozása megváltozott körülmények között

- Élőhely-monitoring (fészkelőhely, táplálkozóhely)

- Telelési csoportosulások vizsgálata

- Predációs nyomás kutatása

Közepes fontosságú, közepes hatékonyságú. Felelös: Agrárminisztérium, megyei vadászati hatóságok, SoE-EMK Vadgazdálkodási és Gerinces Állattani Intézet, SZIE Vadvilág Megörzési Intézet, Magyar Madártani és Természetvédelmi Egyesület

\section{Kommunikáció és nyilvánosság}

C.5.1. A védelem és gazdálkodás hatékonysága és elfogadtatása érdekében a vadgazdálkodásnak jó kapcsolatokat kell kialakítani valamennyi hatósággal.

Nagy jelentöségü, nagy hatékonyságú. Felelös: AM, Kormányhivatalok 
C.5.2. Kellő rendszerességgel tájékoztatni kell a nagyközönséget a balkáni gerle állomány helyzetéröl, hasznosításáról.

Közepes fontosságú, közepes hatékonyságú. Felelös: megyei vadászati hatóságok, OMVV, OMVK, SoE-EMK Vadgazdálkodási és Gerinces Állattani Intézet, SZIE Vadvilág Megörzési Intézet, Magyar Madártani és Természetvédelmi Egyesület

\section{FELHASZNÁLT IRODALOM}

BANKovics A. (1984): Újabb adat a balkáni gerle (Streptopelia decaocto) hazai megjelenéséhez. Aquila 91: 198.

BAUER, H-G. \& BERTHOLD, P. (1997): Türkentaube Streptopelia decaocto. In: BAUER, H-G. \& Berthold, P.: Die Brutvögel Mitteleuropas. Bestand und Gefährdung. Aula-Verlag, Wiesbaden pp. 239-240.

BirdLife International (2004): Birds in Europe. Population estimates, trends and conservation status. Cambridge, UK: BirdLife International (BirdLife Conservation Series No. 12.). $374 \mathrm{p}$.

BozSKo Sz. I. (1976a): A balkáni gerle (Streptopelia decaocto FRIV.) expanziója a Szovjetunió területén. Állattani Közlemények 63: 61-65.

BozSKo Sz. I. (1976b): A balkáni gerle kései fészkelése Debrecenben. Aquila 82: 234.

BozSKo Sz. I. (1979): Ecology and ethology of the Collared Dove (Streptopelia decaocto) in the city of Debrecen. Aquila 85: 85-92.

BozsKo Sz. (1983): The sex and age distribution as well as the major anatomo-morphological characteristics of the population of collared dove (Streptopelia decaocto FRIV.). Aquila 90: $95-104$.

BozsKo Sz. I. \& JuHÁsz L. (1979): A balkáni gerle (Streptopelia decaocto) populációdinamikája Debrecenben. Acta Biologica Debrecina 16: 57-85.

BozSKo Sz. I. \& JuHÁSZ L. (1982): Debrecen város balkáni gerle (Streptopelia decaocto) állományának populációdinamikai vizsgálata. Aquila 88: 91-115.

BozSKo Sz. \& JuHÁsz L. (1984): A balkáni gerle (Streptopelia decaocto Friv.) összehasonlító populációs vizsgálata Magyarország öt megyeszékhelyén (Nyíregyháza, Debrecen, Eger, Győr, Zalaegerszeg). Aquila 91: 115-150.

CRAMP, S. (ed.) (1985): Handbook of the birds of Europe, the Middle East and North Africa. The birds of the Western Palearctic. Volume IV. Terns to woodpeckers. Oxford University Press, Oxford.

CsÁNYI, S. (szerk.)(1999): Vadgazdálkodási Adattár, 1994-1998. Gödöllö, Országos Vadgazdálkodási Adattár.

CsáNYi S. (szerk.)(2001): Vadgazdálkodási Adattár - 2000/2001. vadászati év. Országos Vadgazdálkodási Adattár, Gödöllő.

CSÁNYI S. (szerk.)(2005): Vadgazdálkodási Adattár - 2004/2005. vadászati év. Országos Vadgazdálkodási Adattár, Gödöllő.

CsÁNYI S. (szerk.) (2018): Vadgazdálkodási Adattár - 2017/2018. vadászati év. Országos Vadgazdálkodási Adattár, Gödöllő, 52 pp.

CsÁNyi S., LeHOCZKy R. \& SONKOly K. (szerk.) (2005): Vadgazdálkodási Adattár 2005/2006. vadászati év. Országos Vadgazdálkodási Adattár, Gödöllő. 64 p.

CsÁNyi S., LehOCZKY R. \& SonKOly K. (szerk.) (2008): Vadgazdálkodási Adattár 2007/2008. vadászati év. Országos Vadgazdálkodási Adattár, Gödöllő. 64 p.

CsÁNyi S., LehoczKy R. \& SONKOly K. (szerk.) (2010): Vadgazdálkodási Adattár 2009/2010. vadászati év. Országos Vadgazdálkodási Adattár, Gödöllő. 56 p. 
CSÁNYi S., LehOCZKY R. \& SONKOly K. (szerk.) (2012a): Vadgazdálkodási Adattár 2010/2011. vadászati év. Országos Vadgazdálkodási Adattár, Gödöllő. 52 p.

CsÁNYi S., Tóth K. \& Schally G. (szerk.) (2012b): Vadgazdálkodási Adattár - 2012/2013. vadászati év. Országos Vadgazdálkodási Adattár, Gödöllő. 52 p.

CsánYi S., TÓTH K., KovÁCs I. \& SChally G. (szerk.) (2014): Vadgazdálkodási Adattár 2013/2014. vadászati év. Országos Vadgazdálkodási Adattár, Gödöllő. 48 p.

CsÁNYi S., KovÁcs I., CsÓKÁs A., PUTz K. \& SCHAlly G. (szerk.) (2015): Vadgazdálkodási Adattár - 2014/2015. vadászati év. Országos Vadgazdálkodási Adattár, Gödöllő. 36 p.

CsánYi S., Kovács I., CsóKÁs A., Putz K. \& Schally G. (szerk.) (2016): Vadgazdálkodási Adattár - 2015/2016. vadászati év. Országos Vadgazdálkodási Adattár, Gödöllö, 48 p.

Csányi S., Márton M., Kovács V., Kovács I., Putz K. \& Schally G. (szerk.) (2017): Vadgazdálkodási Adattár - 2016/2017. vadászati év. Országos Vadgazdálkodási Adattár, Gödöllö, 52 p.

Csányi S., Márton M., KovÁcs V., Kovács I. \& Schally G. (szerk.) (2018): Vadgazdálkodási Adattár - 2017/2018. vadászati év. Országos Vadgazdálkodási Adattár, Gödöllö, 52 p.

FARAGÓ S. (1997): Élőhelyfejlesztés az apróvad-gazdálkodásban. A fenntartható apróvadgazdálkodás környezeti alapjai. Mezőgazda Kiadó, Budapest. 356 p.

FARAGÓ S. (2001a): Adatok a magyarországi mezei szárnyasvad fajok fészekalj nagyságaihoz és tojásméreteihez. Magyar Apróvad Közlemények 6: 113-132.

FARAGÓ S. (2001b): Mezei szárnyasvad fajok vonulása Magyarországon, jelölt madarak megkerülése alapján. Magyar Apróvad Közlemények 6: 133-161.

FARAGÓ S. (2006): Galambvadászat. In: FARAGÓ, S. (szerk.): Magyar Vadász Enciklopédia. Totem Kiadó, Budapest. pp. 518-519.

FAragó S. (2009): Balkáni gerle. In: CsÖrgö T., KArCZA Zs., Halmos G., MAGYAR G., GyurÁcz J., Szép T., BAnkovics A., SChMidt A. \& SchmidT E. (szerk.): Magyar madárvonulási atlasz. Kossuth Kiadó, Budapest. pp. 351.

FARAGÓ, S. (2015): Balkáni gerle Streptopelia decaocto (FRIVALDSZKY, 1838). In: FARAGÓ S.: Vadászati állattan. Negyedik, átdolgozott, bővített kiadás. Mezőgazda Kiadó, Budapest. 232-237.

GlutZ von Blotzheim, U. N. \& BAUER, K. M. (1980): Handbuch der Vögel Mitteleuropas. Band 9. Columbiformes - Piciformes. Akademische Verlagsgesellschaft, Wiesbaden

HADARICS T. (1992): Balkáni gerle (Streptopelia decaocto) költési kísérlete feketerigó fészekben. Madártani Tájékoztató 1992 (január-június): 29.

HARASZTHY L. (2019): Balkáni gerle Streptopelia decaocto (FrIVALDSZKY, 1838). In: HARASZTHY L.: Magyarország fészkelö madarainak költésbiológiája. 1. kötet. Fácánféléktől a sólyomfélékig (Non-Passeriformes). Pro Vértes Nonprofit Zrt., Csákvár. pp. 211-218.

Hengeveld, R. (1997): Collared Dove Streptopelia decaocto. In: HaGeMeIJER, W. J. M. \& BLAIR, M. J. (eds.): The EBCC Atlas of European Breeding Birds: Their distribution and abundance. T and D Poyser, London. pp. 388-389.

Jonsson L. (1993): Birds of Europe with North-Africa and Middle East. C. Helm Publisher Ltd/A. \& C. Black Publisher Ltd. London.

JuHÁsz L. (1996): Possibile cause of changes in the dynamics in the Collared Dove (Streptopelia decaocto FrIV.) populations in Hungary. In: BoTEV N. (ed.): Proceedings of the International Union of Game Biologists XXII. Congress ,"The Game and the Man”. Sofia, Bulgaria September 4-8, 1995. PENSOFT Publishers, Sofia - Moscow St. Petersburg. pp. 66-69.

JuHÁsz L. (2016): Köztünk élö madarak. TKK Kereskedelmi Kft., Debrecen. 64 p. 
JuHÁSz L. \& VARGA S. Zs. (2017a): A balkáni gerle (Streptopelia decaocto FRIV.) téli állományának változása Debrecenben. Calandrella 20: 49-52.

JuhÁsz L. \& VARGA S. Zs. (2017b): Population dynamics of Eurasian Collared Dove populations in two Eastern Hungarian Country seats. 33th IUGB Congress. Abstract Books pp. 204.

KEVE A. (1950): A balkáni gerle újabb térfoglalása és újabb adatok ökológiájához. Aquila 5154: $116-122$.

KEVE A. (1960): A balkáni gerle téli költése. Aquila 66: 277-278.

KeVE A. (1962): A balkáni gerle Magyarországon. Aquila 67-68: 71-78.

KeVE-KLEINER A. (1944): A balkáni kacagógerle térhódítása Magyarországon az utolsó évtizedben. Aquila 50: 264-298.

Magyar G., Hadarics T., WaliczKy Z., Schmidt A. \& Bankovics A. (1998): Nomenclator Avium Hungariae. Magyarország madarainak névjegyzéke. Madártani Intézet - MME Winter Fair, Budapest-Szeged. 202 p.

MAKATSCH, W. (1976): Die Eier der Vögel Europas. Eine Darstellung der Brutbiologie aller in Europa brütenden Vogelarten. Band 2. Neumann Verlag, Leipzig-Radebeul. 460 p.

MME NOMENCLATOR BIZOTTSÁG (2008): Magyarország madarainak névjegyzéke. Nomenclator avium Hungariae. An annotated list of the birds of Hungary. Magyar Madártani és Természetvédelmi Egyesület, Budapest. 278 p.

MME (2019): Magyarország madarai: Balkáni gerle. http://www.mme.hu/magyarorszagmadarai/madaradatbazis-strdec Letöltés dátuma: 2019-07-18

NowaK E. (1960): Über die Ausbreitung und Verbreitungsgrenze der Türkentaube Streptopelia decaocto (Friv.) in Osteuropa. Proceedings of the XIIth International Ornithological Congress, Helsinki 1958. pp. 557-562.

PIKUlA J. \& KuBÍK V. (1978): Die Brutökologie der Türkentaube Streptopelia decaocto im Milieu der Stadt Brno. Acta Scientiarum Naturalium Academiae Scientiarum Bohemoslovacae Brno XII. Nova Series. 10. 40 p.

RÉKÁSI J. (1975): Napraforgótábláról begyüjtött balkáni gerlék (Streptopelia decaocto) tápláléka. Aquila 80-81: 287-288.

RÉKÁSI, J. (1980): Adatok a balkáni gerle (Streptopelia decaocto) táplálkozásbiológiájához. Állattani Közlemények 67: 99-108.

RÉKÁSI J. (1983): Madarak táplálkozás-biológiai vizsgálata nagyüzemi napraforgótáblákon. In: KÁRPÁTI L. (szerk.): A Magyar Madártani Egyesület Elsö Tudományos Ülése. Sopron, 1982. Sopron. pp. 77-91.

RÉKÁSI J. (2000): Balkáni gerle Streptopelia decaocto. In: HARASZTHY L. (szerk.): Magyarország madarai. Második, javított kiadás. Mezőgazda Kiadó Budapest: 206207.

RÉKÁSI J. \& RichNOVSZKY (1974): Angaben zur Frage der Schneckennahrung bei Vögeln. Soosiana 2: 45-50.

Solti B. (2010): A Mátra Múzeum Madártani gyüjteménye III. Németh Márton tojásgyüjtemény. Folia Historico Naturalia Musei Matraensis Supplementum 5: 5-275.

STOLlmanN A. (1957): A balkáni gerle szokatlan fészkeléséröl. Aquila 63-64: 285-286, 343.

TOMASZ J. (1955): Adatok a balkáni gerle ökológiájához. Aquila 59-62: 101-143.

TUCKER G. M. \& HEATH M. F. (1994): Birds in Europe: their conservation status. Cambridge, U.K. /BirdLife Conservation Series 3.

VARGA S. Zs. \& JUHÁsZ L. (2018): Evaluation of population parameters and biometric data of an Eurasian Collared Dove (Streptopelia decaocto FRIV.) population in the Great Plain of Hungary. Acta Agraria Debreceniensis. 2018/75: 89-92. 